\title{
1. INTRODUCTION, SUMMARY, AND EXPLANATORY NOTES, THE MIDDLE AMERICA TRENCH TRANSECT, DEEP SEA DRILLING PROJECT LEG 671
}

\author{
William T. Coulbourn, Scripps Institution of Oceanography, La Jolla, California
}

\section{INTRODUCTION}

Seismology has outlined the locations, directions, and rates of lithospheric plate convergence for most of the active margins of the world, yet the expression of that interaction in the geologic features of the setting remains problematic. On a larger scale, the mechanisms by which plate convergence causes mountains to rise above subduction zones and the origin of continental rocks themselves are a matter of conjecture.

With these broad questions in mind, the IPOD Active Margin Panel (AMP) selected the Middle America Trench for study. Experience in drilling along other convergent margins indicated that to identify accreted rock and sediment within a subduction complex (Fig. 1), juxtaposed and disparate lithologies as well as detailed age resolution are necessary. A summary of drilling results in similar tectonic settings indicates some of the difficulties encountered (Fig. 2). Poor drilling conditions, and brecciated samples were common at these sites. Conspicuous in their general absence are calcareous chalks and basalt, rocks diagnostic of ocean-basin provenance. Diatomaceous hemipelagic mud accounts for the preponderance of samples cored from these wells. Carbonate-rich hemipelagic muds, sands, conglomerates, ash beds, and exotic pebbles comprise most of the remaining components. In this setting, even under the best of circumstances, it may be difficult to distinguish sediment provenance. For example, at the high-latitude sites of Legs 18 and 19, low faunal diversity and a high influx of Pleistocene terrigenous sediment prevented differentiation of oceanic and slope deposits (Kulm, von Huene, et al., 1973). At the Leg 60 sites, because of the great depth of the Pacific Plate, pelagic red brown clays, not chalks, are brought into the subduction zone; those clays would be difficult to trace were they tectonically mixed with hemipelagic sediments of the Mariana Arc. A similar problem involves the provenance of sands cored at the Leg 66 sites (Moore et al., 1980). Are they slope sands or are they sands from the Trench axis that are now incorporated into the continental margin? Because the influx of terrigenous sediment is low and faunal diversity high relative to other convergent margins, the AMP chose the Guatemalan transect (Fig. 3) as one of two to be drilled across the Middle America Trench (von Huene, Aubouin, et al., 1980).

\footnotetext{
${ }^{1}$ Aubouin, J., von Huene, R., et al., Init. Repts. DSDP, 67: Washington (U.S. Govt. Printing Office)
}

The Oaxaca transect, located off southern Mexico and drilled during Leg 66, sampled a truncated margin and subduction complex (Moore et al., 1979; Karig et al., 1978). In contrast, the Guatemala transect was selected because accretion was thought to have continued in this area during most of the Tertiary (Seely et al., 1974; Seely, 1979). Site surveys conducted by the University of Texas Marine Science Institute provided multichannel seismic records, among which profile GUA-13 was chosen as the location for Leg 67 drill holes (Fig. 4). Selection of this transect arises in part from the fact that it includes a portion of the San José Canyon, thus layers of hemipelagic drape may have been stripped away by erosion, allowing quicker access to deep horizons.

By studying the continental margin off Guatemala we hoped to strengthen the tie between offshore and onshore geology, to describe the stratigraphic sequence from the continental slope to the subducting oceanic plate beneath, to recover in ash layers a record of Central American volcanism, and to test the hypotheses describing active-margin tectonics. Specifically, the Guatemalan transect was chosen to sample and to map the geology of the "type region" for the Trench-Slope Model (Seely, et al., 1974). This model is commonly referred to in the current geologic literature (e.g., Moore, et al.; 1980; Le Quellec, et al., 1980; Shipley, et al., 1980; Scientific Party, 1980; Coulbourn and Moberly, 1977; Moore and Karig, 1976; White and Klitgord, 1976; Karig and Sharman, 1975; Karig, Ingle, et al., 1975; Prince and Kulm, 1975). The Trench-Slope Model in its general form describes the geologic evolution of a prism-shaped volume located above a subducting oceanic plate and seaward of an overriding continental lithospheric plate (Fig. 1). In one of the earlier conceptual drawings of such a setting, Den and Yoshi (1970) portrayed an aggregated mass of sediment and rock analogous to the trench-snow plow cartoon later drawn by Helwig and Hall (1974). In effect, the continental "plow" is envisioned as scraping rock and sediment from the surface of the downgoing oceanic plate. The idea of pasting of offscraped sediment and rock against the face of an overriding plate was elaborated on in the Trench-Slope Model to embody a concept of accretion by imbricatethrust faulting (Seely et al., 1974). The idea implies a slicelike stacking of rock and sediment within an "accretionary prism" (Karig and Sharman, 1975), stratigraphic reversals within the section, and uplift of the entire stack as incoming rock and sediment are added to the base of the pile. The concept has gained general acceptance in the literature, particularly because seismic- 

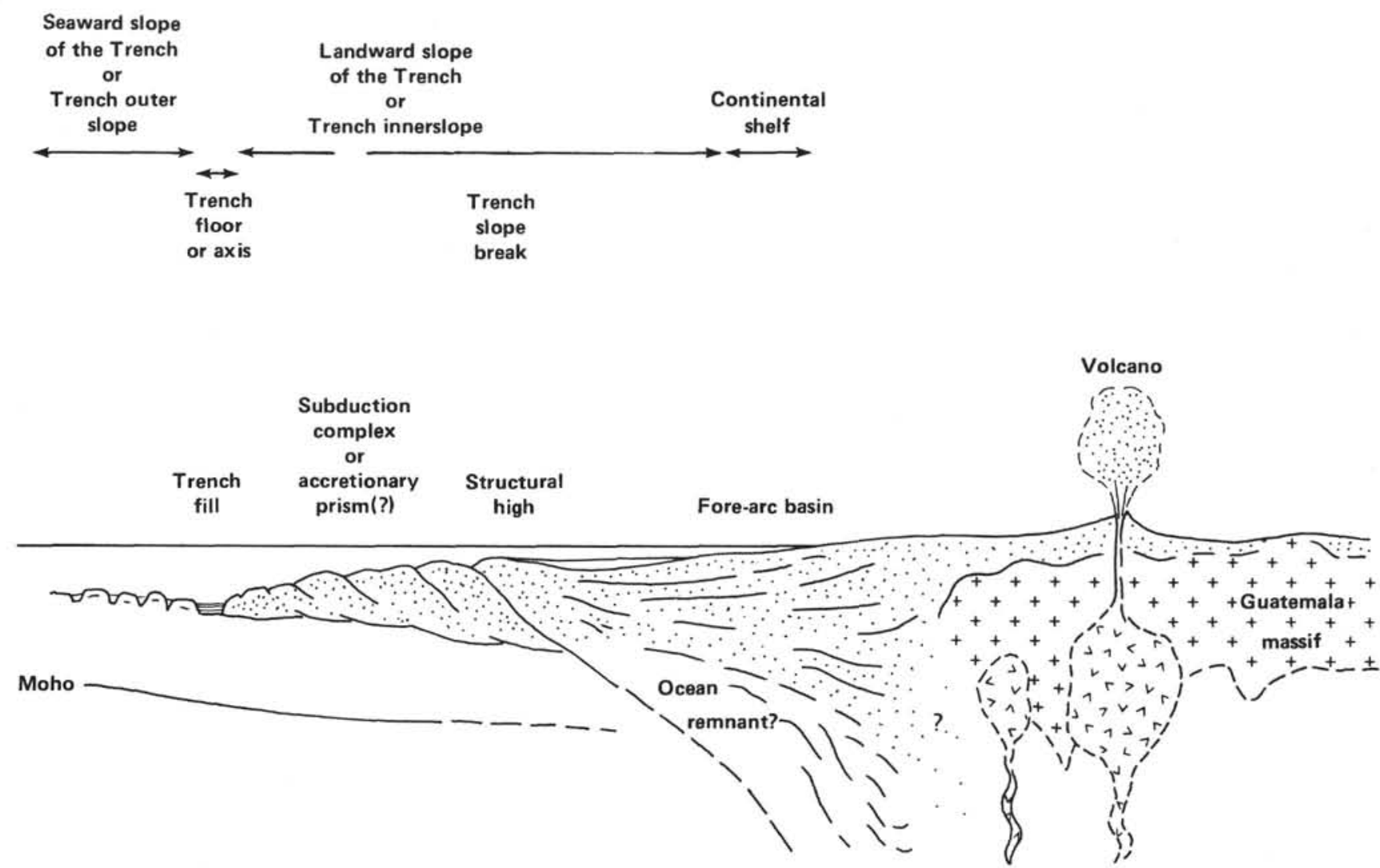

Figure 1. Trench-Slope Model. (The drawing and terminology are adapted from Seely et al. [1974] and Dickinson and Seely [1979].)

reflection records frequently show landward-dipping reflectors within fore-arc basins and subduction complexes of most convergent margins (i.e., Silver, 1971; Grow, 1973; Seely, et al., 1974; Beck and Lehner, 1974; Karig and Sharman, 1975; Montecchi, 1976; Hamilton, 1977; Coulbourn and Moberly, 1977; Ladd et al., 1978; Ladd and Watkins, 1979; Shipley, et al., 1980, Le Quellec, et al., 1980). Indeed, that geometry is evident even in the early profiles made across the landward slope of the Middle America Trench (Ross and Shor, 1965), and it is clearly visible in profile GUA-13, the transect along which Leg 67 sites were drilled (Fig. 4). Opinions regarding the subject are not unanimous, however. Alternative viewpoints generally postulate subduction of a good part, if not most, of the incoming pelagic sediment and basalt, accompanied perhaps by "tectonic erosion" of the overriding lithospheric plate (Scholl and Marlow, 1974; Hussong et al., 1976; Scholl, et al., 1977; Hussong and Wipperman, 1981; Hussong and Uyeda, 1981). A sketch of two possible end members summarizes the extent of our uncertainty regarding processes within this geologic setting (Fig. 5).

Uplifted benthic foraminifers have been recovered on the slopes offshore of northern California (Silver, 1971) and offshore of Sumatra (Moore et al., 1980), and transferred pelagic sediment was cored from the Peruvian margin (Kulm et al., 1974). The rocks of Barbados (Beckmann, 1953; Speed, 1978), Nias Island, Indonesia (Moore and Karig, 1980), and Isla Moca and the Arauco Penin- sula in Chile (Kaizuka et al., 1973) are a few locales where uplifted rock and sediment are thought to represent structural highs bordering modern subduction zones. Ancient subduction complexes and uplifted marine sediment are exposed in many places, among them the $\mathrm{Ni}$ coya Peninsula of Costa Rica (see Azéma and Tournon, this volume). These older oceanic rocks and sediment are now pasted against continental rocks. Yet as Karig, Ingle, et al. (1975) prefaced their discussion of Site 298 drilled in the Nankai Trough, " . . . . no hole has successfully penetrated the lower slope to reveal how the separation of trench sediments from the downgoing plate occurs." That statement is true to date even after 19 holes have been drilled into various convergent margins; however, the lithologies recovered at those sites do suggest that subsidence rather than uplift is the dominant process (Fig. 2). Within modern subduction zones, where are the uplifted, accreted, and imbricated oceanic rock and sediment? We hoped to drill deep enough to answer this question.

\section{SUMMARY OF RESULTS}

The geophysical data at hand and the initial analyses of samples from the seven drill sites of the DSDP Leg 67 Guatemala transect indicate that an accretionary prism of deformed, dewatered, and imbricated pelagic sediments and basalt must occupy a small volume, if indeed it is to be found at all, within the Guatemalan margin. The Trench-Slope Model, as it is described by Seely et 
al. (1974), Karig and Sharman (1975), and Dickinson and Seely (1979), does not easily explain our drilling results. In particular, Site 494, located $3 \mathrm{~km}$ landward and 580 meters above the Trench axis, penetrated 367 meters without retrieving a stratigraphic section resembling that predicted for an "accretionary prism" (see Fig. 4). Evidence of imbrication and uplift of rock and sediment is lacking, whereas indications of gravity, induced features, and recycling of sediment downslope are abundant. Even a Globotruncana-rich mudstone from a sub-bottom depth of 300 meters includes coccoliths indicative of nearshore provenance, therefore that rock is probably not a scrap of transferred Cocos Plate sediment.

Gas hydrates were encountered on the continental slope at Sites 496,497 , and 498 so that we did not reach the deep structures that were our primary objectives. The gas hydrates were in the form of frozen pieces of vitric sand that effervesced vigorously after self-ejection from the core barrel. Methane/ethane ratios of these gases varied considerably among the sites.

At both Sites 496 and 497, near-vertical, dark colored veinlets are attributed to dewatering of the sediment. Microfossils document a history of downslope transport. Bed forms diagnostic of provenance are generally lacking, but conglomerates indicate intervals of rapid sedimentation that punctuated a generally quiet environment of deposition. These deposits probably accumulated in a Trench slope setting comparable to their present-day surroundings.

Drilling at Site 495 documents that the age of Cocos Plate basalt now at the seaward edge of the Middle America Trench is early Miocene. As "Plate Stratigraphy" predicts (Berger and Winterer, 1974), the Site 495 sedimentary sequence records the passage of this site from the East Pacific Rise crest to depths beneath the calcite compensation depth. Hemipelagic muds cap Miocene chalks and suggest mechanisms capable of transporting sediment hundreds of kilometers seaward of its source area on the Guatemalan margin.

Sites 499 and 500 within the Trench axis document the tensional stress field predicted for the flexed and subducting oceanic plate (Hanks, 1971; Dean and Drake, 1978). In particular, the section drilled within the Trench axis shows that horst and graben lie beneath turbidites ponded in the Trench axis.

\section{EXPLANATORY NOTES}

\section{Biostratigraphic Zonation}

During Leg 67 we recovered a variety of sediment ranging from chalk to turbidites to hemipelagic sediment draped over the continental margin and landward edge of the Cocos Plate. The microfossils within these sediments were deposited over a span of time from the Late Cretaceous to the Recent. Calcareous benthic and planktonic foraminifers, and calcareous nannoplankton were recovered in spotty concentrations within hemipelagic sediment cored at each of the sites, including those in the Trench axis. Their presence at great depth attests to rapid transport and burial. Dissolution effects are clearly recorded at Site 495 , where basal Miocene foraminifer-nannofossil chalk overlying nannofossil chalk, red brown clay, and a capping of hemipelagic, diatomrich clay document the passing of the site beneath the calcite compensation depth (CCD) and ultimately into the nearshore, tropical upwelling zone.

The Leg 67 micropaleontologists synthesized zonal schemes for planktonic foraminifers, calcareous nannofossils, and radiolarians in order to date the stratigraphic horizons and to reconstruct the paleoenvironmental histories for our drill sites (Figs. 6 and 7). Within the Neogene time scale, the assignment of absolute ages to the zonal boundaries and the correlation of Blow's (1969) planktonic-foraminiferal zones for tropical regions with those of Bukry (1975) for calcareous nannoplankton are from Berggren (1973), and Berggren and van Couvering (1964). The Pliocene planktonic foraminiferal scheme is based on Jenkins and Orr (1972) for the eastern Pacific. Ages recognized for radiolarian zone boundaries of Nigrini (1971) for the Quaternary and Riedel and Sanfilippo (1978) for the Tertiary are those proposed by Theyer (1974), Theyer and Hammond (1974), and Theyer et al. (1978).

\section{Lithologic Classification}

The basic classification system used here was devised by the JOIDES Panel on Sedimentary Petrology and Physical Properties (SPPP) and adopted for use by the JOIDES Planning Committee in March 1974. Leg 67 shipboard scientists have modified this classification because of the dominantly hemipelagic nature of the sediments recovered and the difficulty in accurately determining silt/clay ratios in smear slides. This classification is descriptive, and divisions between different types of sediment are somewhat arbitrary. Following is a brief outline of the conventions and descriptive data used to construct this classification.

\section{Descriptive Data}

In this classification, composition and texture are the only criteria used to define the type of sediment or sedimentary rock. Composition is most important for describing sediments deposited in the open ocean, whereas texture is significant for hemipelagic and nearshore sediments. These data come principally from visual estimates of smear slides examined for areal abundance and size components under a petrographic microscope. As such these data may differ somewhat from more accurate analyses of grain size, carbonate content, and mineralogy. From past experience, quantitative estimates of distinctive minor components are accurate to within 1 to $2 \%$, but for major constituents accuracy is poorer, $\pm 10 \%$. All smear-slide estimates were done aboard the Glomar Challenger.

Where applicable we used one or several modifiers in naming the type of sediment encountered. In all cases the dominant component appears last in the name, minor components precede, with the least-common constituent listed first. If minor constituents occur in amounts less than $10 \%$ they are not included in the name. This convention also holds for zeolites, $\mathrm{Fe}$ - and 


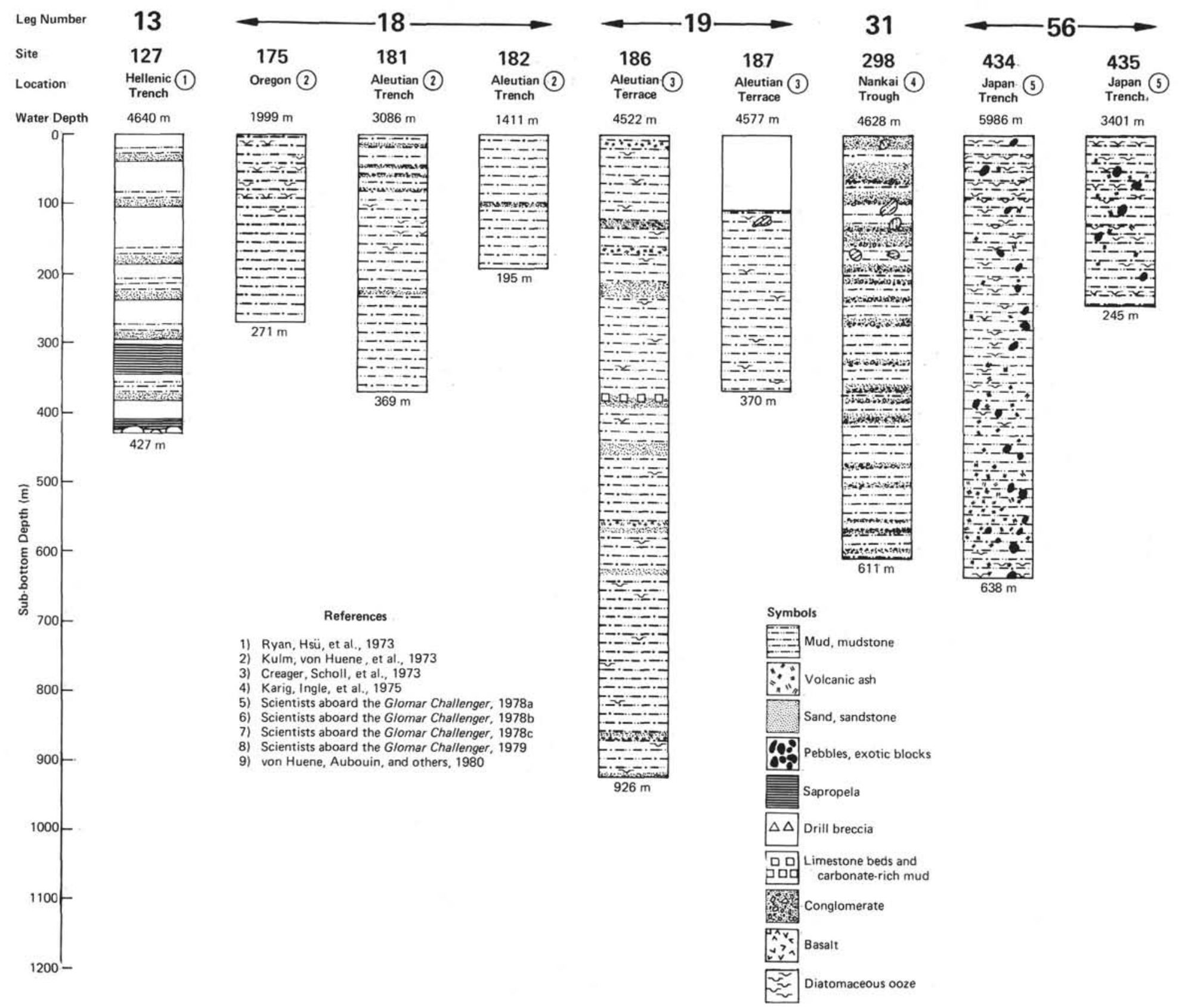




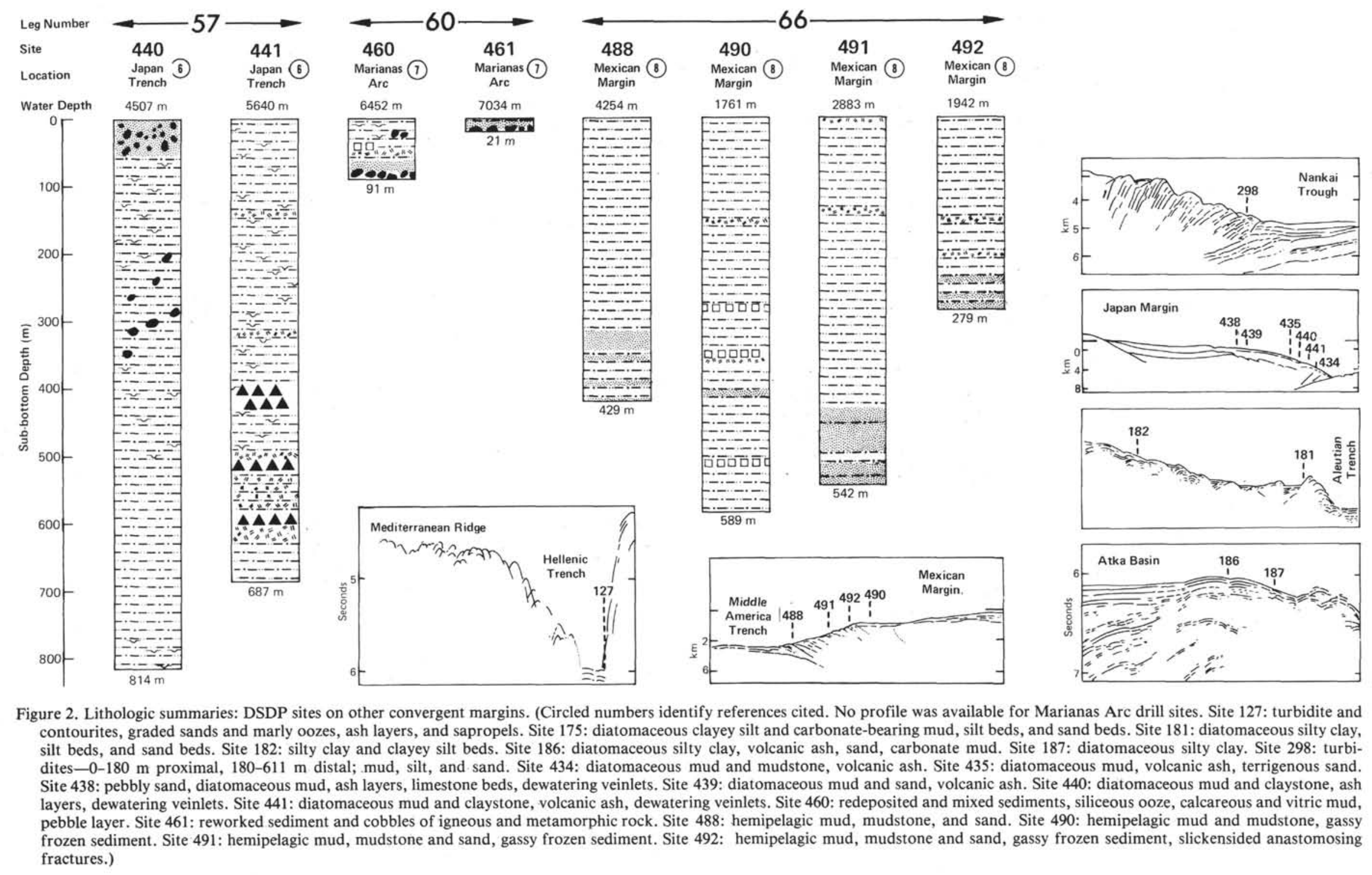




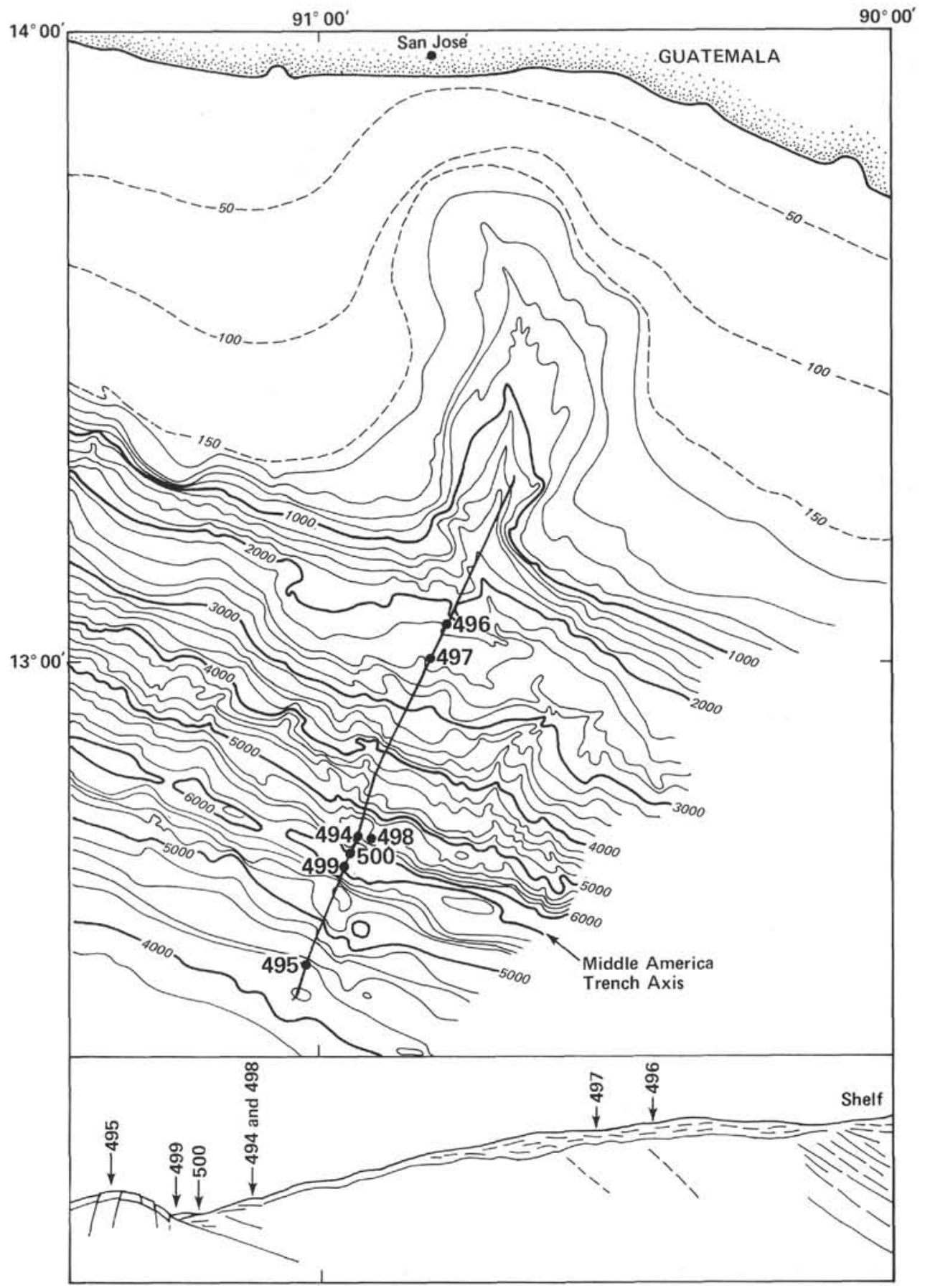

Figure 3. Location map, general bathymetry, and structural cross-section for Leg 67 sites.

Mn-micronodules, and other indicators of very slow rates of sedimentation or nondeposition. Often these minerals are conspicuous even though greatly diluted.

\section{Induration of Sediments}

We recognize three classes of induration or lithification for all sediments.

A. For calcareous sediments and sedimentary rocks; the three classes are based on categories formulated by Gealy, et al. (1971):
1. Soft $=$ ooze; has little strength and is readily deformed under pressure of a finger or the broad blade of spatula.

2. Firm = chalk; is partially lithified and is readily scratched by a fingernail or the edge of a spatula.

3. Hard = limestone; dolostone; is well lithified and cemented; is resistant to being scratched (or impossible to scratch) with a fingernail or the edge of a spatula. 


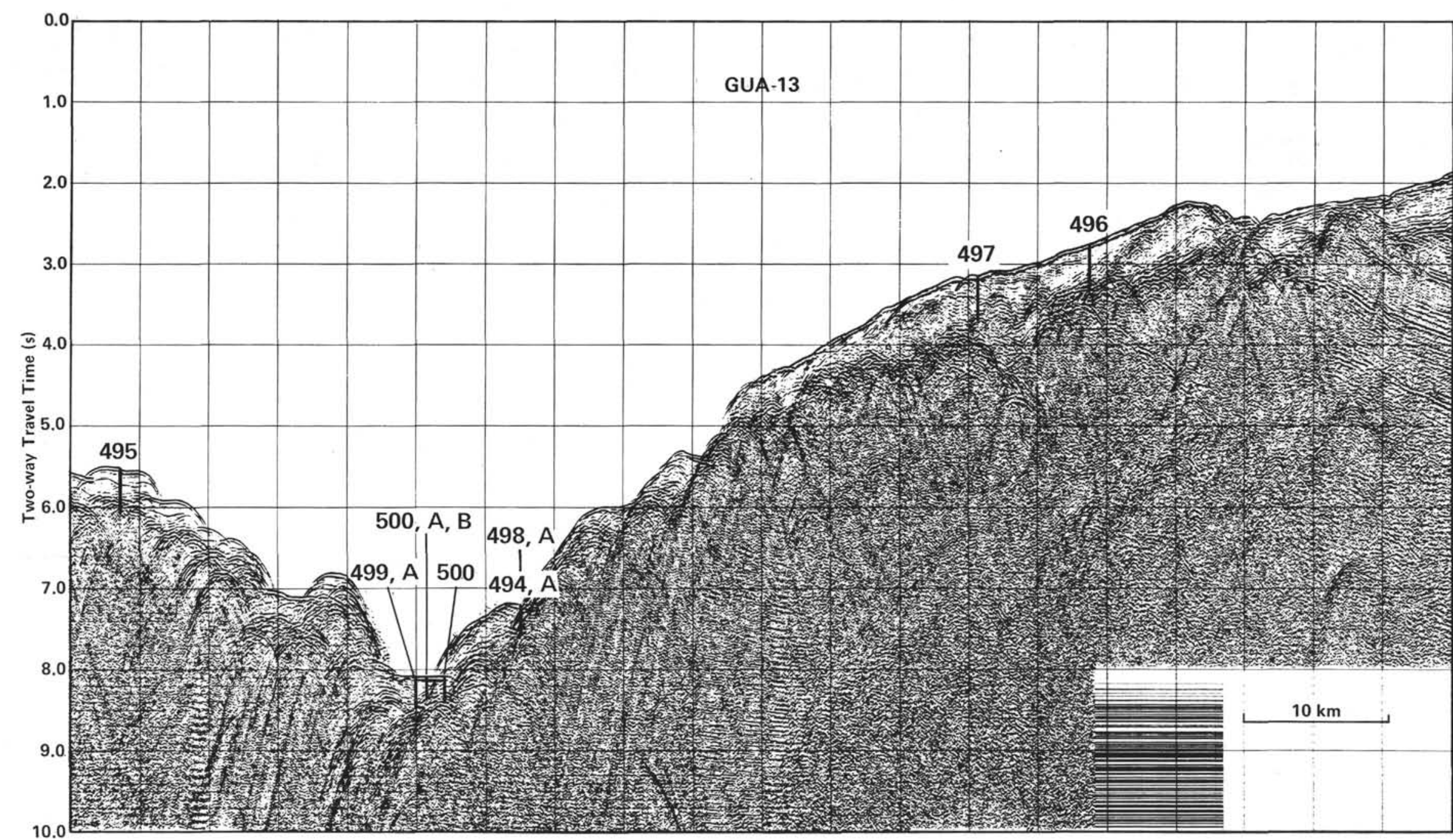

Figure 4. Seismic reflection profile GUA-13 and location of Leg 67 sites (after Ladd et al., 1978; Ibrahim et al., 1979). 


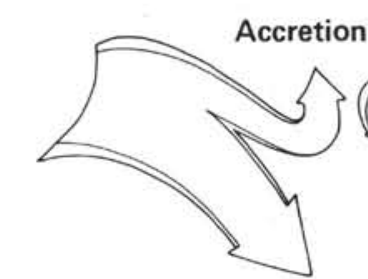

Subduction

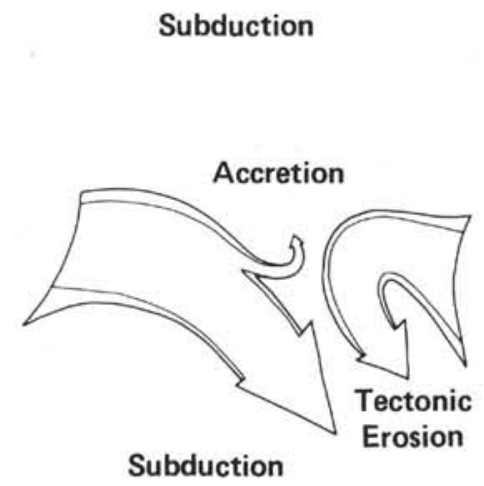

Subduction

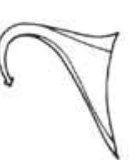

Tectonic Erosion

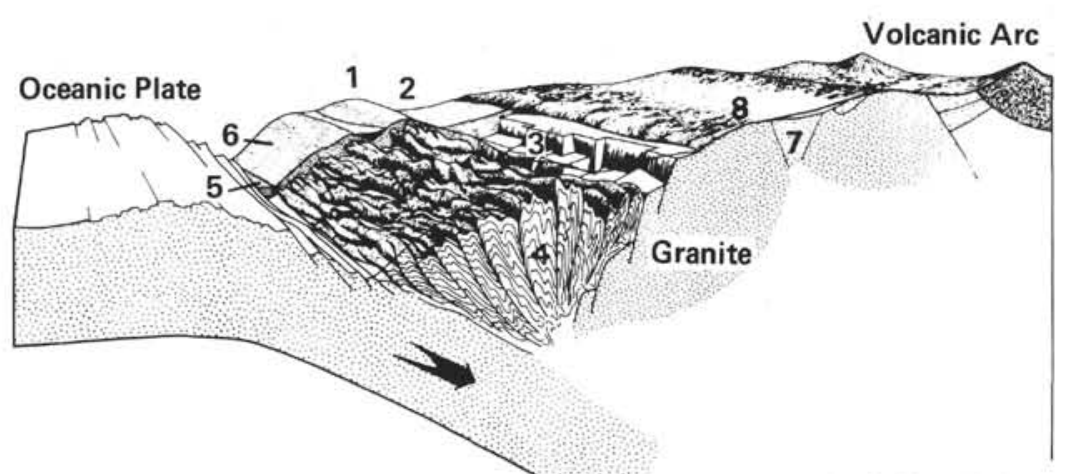

Volcanic Arc

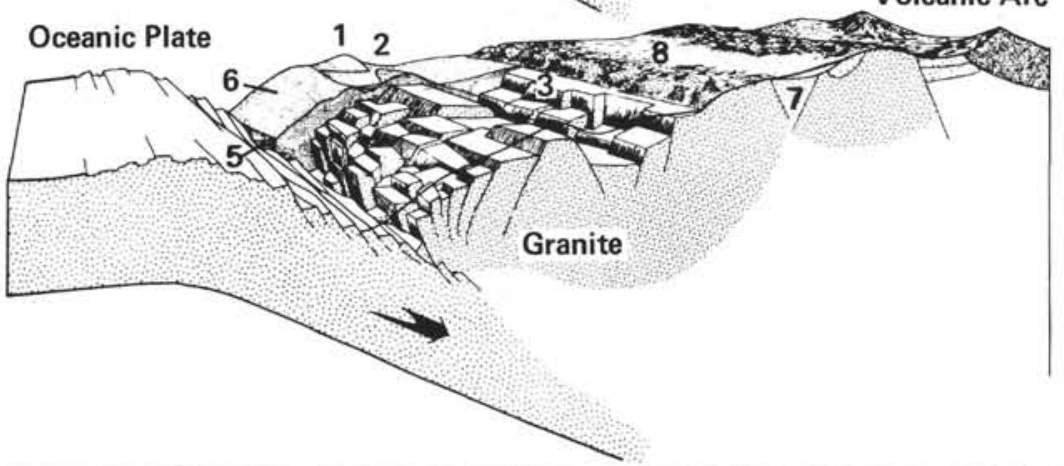

Figure 5. Accretionary and erosional end members for convergent margins (from Coulbourn, 1981). (Arrows indicate relative amounts of rock and sediment subducted, accreted, or "tectonically eroded." $1=$ structural high; $2=$ fore-arc basin; $3=$ block-faulted continental rock; $4=$ accretionary prism; $5=$ Trench axis turbidites; $6=$ hemipelagic drape; $7=$ ancient sediments; and $8=$ coastal batholith.)

\begin{tabular}{|c|c|c|c|c|c|c|c|c|c|}
\hline & & & & & Age (m.y. & & & & \\
\hline & 1. & & & & & & 37 & & \\
\hline 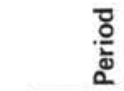 & Quaternary & $\begin{array}{c}\text { upper } \\
\text { Pliocene }\end{array}$ & $\begin{array}{l}\text { lower } \\
\text { Pliocene }\end{array}$ & $\begin{array}{c}\text { upper } \\
\text { Miocene }\end{array}$ & $\begin{array}{c}\text { middle } \\
\text { Miocene }\end{array}$ & $\begin{array}{c}\text { lower } \\
\text { Miocene }\end{array}$ & Oligocene & Eocene & $\begin{array}{c}\text { Upper } \\
\text { Cretaceous }\end{array}$ \\
\hline 494 & $1-4$ & & & & & & & & \\
\hline $494 \mathrm{~A}$ & $1-16$ & 17 & $-20,4$ & 20,4 & $20,4-$ & -22 & $22 ?$ & $\begin{array}{c}\text { m. Eocene } \\
23-27\end{array}$ & $\begin{array}{c}\text { Maestrichtian } \\
28-30\end{array}$ \\
\hline 495 & $1-6$ & $7-11$ & $12-15$ & $13-17$ & & & & & \\
\hline 496 & $1-24$ & 25 & -26 & $27-28$ & & & . & & \\
\hline 497 & $1-17$ & $18-32$ & $32-42$ & $38-42$ & & & & & \\
\hline 498 & $1-2$ & & & & & & & & \\
\hline $498 A$ & $1-4$ & 5 & $-5, \mathrm{CC}$ & $5, \mathrm{CC}$ & & 14 & & & \\
\hline 499 & $1-21$ & 22 & & 23,1 & 23 & 25 & & & \\
\hline $499 A$ & $1-5$ & & & & & & & & \\
\hline 499B & & & & & 1 & $1-9$ & & & \\
\hline 500 & $1-10,2$ & & & & & $10,2-17$ & & & \\
\hline $500 A$ & $1-2$ & & & & & & & & \\
\hline $500 \mathrm{~B}$ & $1-2$ & & & & & & & & \\
\hline
\end{tabular}

Figure 6. Paleodepths of Leg 67 drill sites. (Numbers represent cores; core and section are separated by a comma.) 


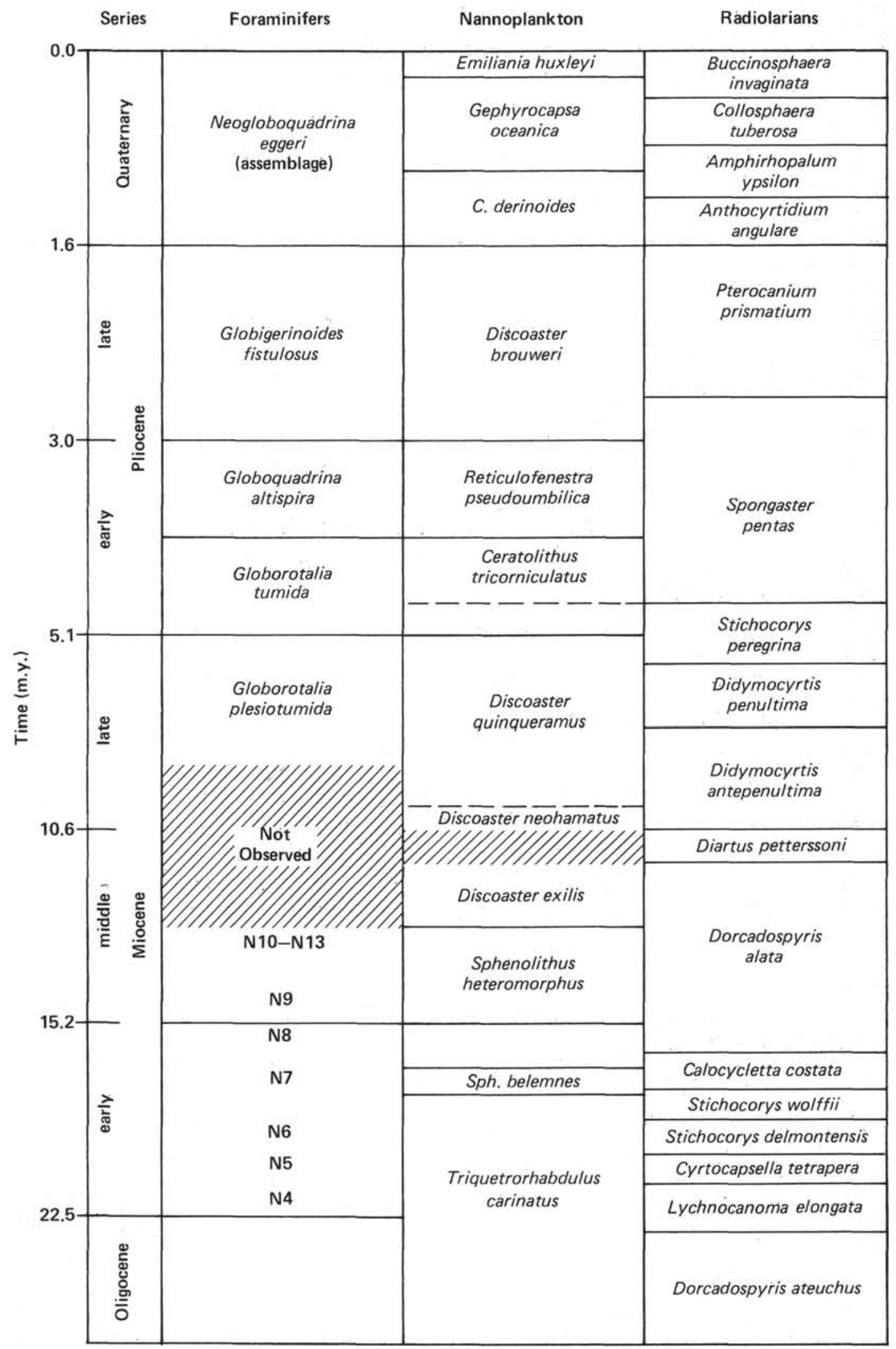

Figure 7. A summary of the biostratigraphic zonal schemes for microfossil groups used in Leg 67 studies. 
B. The three classes of induration for transitional carbonates, siliceous, pelagic, and terrigenous sediments are as follows:

1. Soft-sediment core may be split with a wire cutter.

2. Firm-partially lithified, but fingertip pressure leaves an indentation.

3. Hard-cannot be compressed by fingertip pressure.

\section{Types of Sediments and Compositional Boundaries}

\section{Pelagic Clay}

Pelagic clay is principally an authigenic deposit that accumulates at a very slow rate. The class is often termed brown clay or red clay.

1. The boundary between pelagic clay and terrigenous sediments is at the point where authigenic components such as $\mathrm{Fe} / \mathrm{Mn}$ micronodules, zeolites, etc., become common $(>10 \%)$ in smear slides, indicating pelagic clay. The accumulation rates of pelagic clay and terrigenous sediments are very different, therefore transitional deposits are exceptional.

2 . The boundary of pelagic clay with siliceous-biogenic sediments is where there is less than $30 \%$ siliceous remains.

3 . The boundary between pelagic clay and calcareous-biogenic sediment occurs as a sharp lithologic and color contrast in our cores and as such requires no special explanation.

\section{Pelagic-Siliceous-Biogenic Sediment}

Pelagic-siliceous-biogenic sediment is distinguished from pelagic clay because the siliceous-biogenic sediment has more than $30 \%$ siliceous microfossils. Siliceous-biogenic sediments are distinguished from a calcareous category by exhibiting a calcium-carbonate content of less than $30 \%$.

For a pelagic-siliceous-biogenic sediment with $\sim 30$ to $100 \%$ siliceous fossils, the following terminology is used:

1. Soft: siliceous ooze (radiolarian ooze, diatomaceous ooze, etc., depending on the dominant fossil component).

2. Hard: radiolarite, diatomite, chert, or porcellanite.

3. Compositional qualifiers: diatoms and radiolarians may be the principal components, thus one or two qualifiers may be used. The order of the two modifiers in the terms is dependent on the dominant fossil type; the most dominant component is listed last and the minor component first.

\section{Pelagic-Biogenic-Calcareous Sediment}

Pelagic-biogenic-calcareous sediment is distinguished by a biogenic $\mathrm{CaCO}_{3}$ content in excess of $30 \%$. There are two classes: (1) pelagic-biogenic-calcareous sediments that contain 60 to $100 \%$ biogenic $\mathrm{CaCO}_{3}$ and (2) transitional biogenic-calcareous sediments that contain 30 to $60 \% \mathrm{CaCO}_{3}$.
1. For the pelagic-biogenic-calcareous sediment with 60 to $100 \% \mathrm{CaCO}_{3}$ the following terminology is used:

a. Soft: calcareous ooze

b. Firm: chalk

c. Hard and cemented: limestone

d. Compositional qualifiers: if nannofossils and foraminifers are the principal components, then one or two qualifiers may be used.

2. The transitional biogenic-calcareous sediments with 30 to $60 \% \mathrm{CaCO}_{3}$ are termed marl or marlstone depending if they are soft or hard.

\section{Terrigenous Sediments}

Terrigenous sediments are distinguished by a terrigenous component in excess of $30 \%$ and siliceous and authigenic components each less than $10 \%$. These sediments are the most common type encountered on Leg 67.

Sediments in this category are subdivided into textural groups (by smear-slide estimation or grain-size analysis) on the basis of the relative proportions of sand, silt, and clay. The size limits are those defined by Wentworth (1922). Textural classification follows the triangular diagram (Fig. 8).

The sediment that is transitional between pelagic and terrigenous sediments is termed hemipelagic. This is the dominant type of sediment encountered during continental margin drilling. As such it is treated separately.

\section{Hemipelagic Sediments}

Hemipelagic sediments are distinguished by a terrigenous component in excess of $30 \%$, a total nonbiogenic component in excess of $40 \%$, and a biogenic silica content in excess of $10 \%$. Besides the terrigenous component, hemipelagic sediments are usually rich in biogenic silica (usually diatoms, because of coastal upwelling)

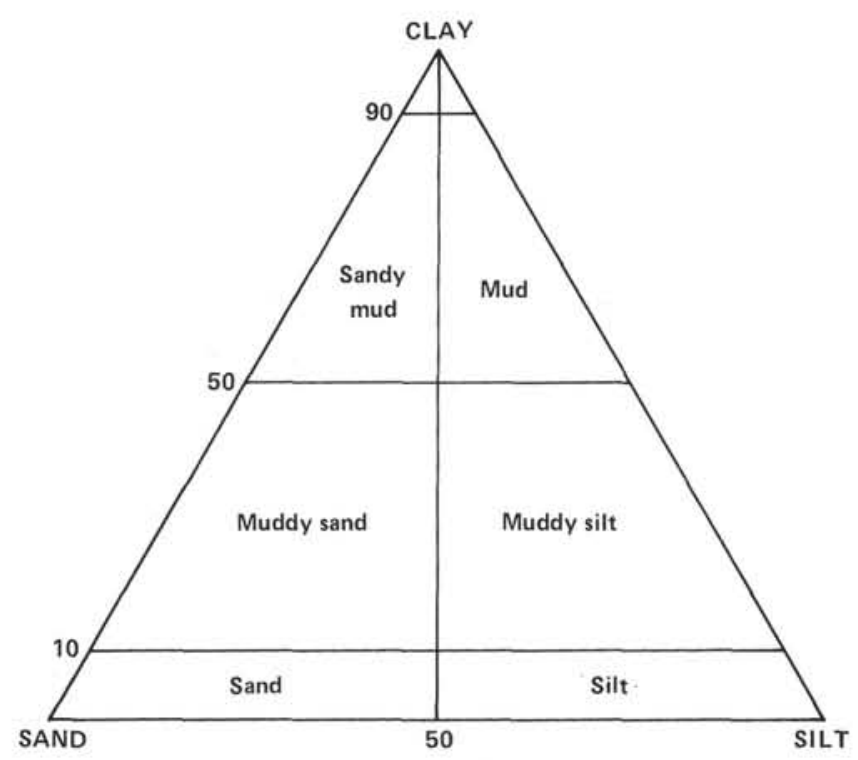

Figure 8. Terrigenous sediment classification used during Leg 67. 
and volcanic ash (predominantly along active margins). When biogenic silica contents are greater than $10 \%$, the dominant siliceous biogenic component is used in the name.

Components such as sand, diatoms, radiolarians, spicules, ash, and so on are used as qualifiers to the original sediment description, if their abundance is 10 to $30 \%$ of the sediment. Within the textural group and the component group, the modifiers are listed in order of increasing sedimentary abundance.

\section{Volcanogenic Sediments}

Pyroclastic rocks are described according to the textural and compositional scheme of Wentworth and Williams (1932).

The compositions of these pyroclastic rocks are described as vitric (glass), crystalline, or lithic. Sediments rich in ash are described in the following manner:

\begin{tabular}{rll}
\hline$\%$ Ash & Soft Sediment & \multicolumn{1}{c}{ Indurated } \\
\hline $0-10$ & Mud & Mudstone \\
$10-30$ & Vitric mud & Vitric mudstone \\
$30-60$ & Muddy ash & Tuffite \\
$>60$ & Ash & Tuff \\
\hline
\end{tabular}

\section{Qualifiers}

In general, constituents accounting for 10 to $30 \%$ of the sediment may be listed as qualifiers in the name of the sediment, such as vitric diatomaceous mud or vitric muddy diatomaceous ooze. If more than one such qualifier is used, they are listed in order of increasing abundance in the sediment.

\section{Classification of Igneous Rocks}

We informally classified igneous rocks recovered on Leg 67 according to mineralogy and texture determined by visual inspection of hand specimens and thin sections.

\section{Physical Properties-Procedures}

A thorough discussion of physical properties is presented by Boyce (1976) with respect to equipment, methods, errors, correction factors, and problems related to coring disturbance. Only a brief review of methods employed on Leg 67 is given here.

\section{Velocity}

Compressional-wave velocity was measured on the Hamilton Frame Velocimeter by timing a $400-\mathrm{kHz}$ pulse between two transducers and by measuring the distance across the sample with a dial gauge. Measurements were made at laboratory temperature and pressure. Soft, unconsolidated sediments were generally measured on the split core; correction factors established by Boyce (1976) were used to compensate for increased thickness and travel time due to the liner $(0.256 \mathrm{~cm}$ and $1.180 / \mu \mathrm{s}$, respectively). In the case of consolidated sediments, a piece was removed from the core and trimmed carefully to form two parallel surfaces to ensure good contact with the transducer heads. Water, glycerine, and Dow-11 sili- cone lubrication compound were used to make acoustical contact between the sample and the transducers.

Calibration of the velocimeter consisted of making numerous measurements through lucite, aluminum, and brass standards of varying thicknesses to obtain a calibration constant for each of three $\mu \mathrm{s} / \mathrm{cm}$ settings on the DSDP Tektronix 485 oscilloscope used to make the travel-time measurements. This calibration constant reflects the position picked by the operator as representing the first break from horizontal of the sonic signal.

\section{GRAPE}

The Gamma Ray Attenuation and Porosity Evaluator (GRAPE) was used to determine wet-bulk density based on the attenuation of gamma rays by the sample. Boyce (1976) discusses the theoretical aspects of this process in detail. During Leg 67 the GRAPE was used in two modes: (1) continuous GRAPE, in which most sections of the core were irradiated; continuous "corrected" wetbulk density (relative to quartz) was plotted on an ana$\log$ graph; and (2) two-minute GRAPE, in which the gamma count through a small piece of the core was measured for two minutes, followed by a similar count through air and/or a quartz standard.

\section{Continuous GRAPE}

Prior to running each core through the device, an aluminum standard was measured. A density of 2.60 $\mathrm{Mg} / \mathrm{m}^{3}$ was assigned to the $6.61-\mathrm{cm}$ (diameter) aluminum standard analog record and a density of $1.0 \mathrm{Mg} / \mathrm{m}^{3}$ to the 2.54-cm (diameter) aluminum standard analog record. Linear interpolation of the GRAPE analog data between these values yielded an "empirical" wet-bulk density of the sediment sample in the core $\left(\varrho_{b c z}\right)$. If the sample completely filled the core, then $\varrho_{b c}=\varrho_{b c z}$, where $\varrho_{b c}=$ "corrected" wet-bulk density (relative to quartz). Then

$$
\varrho_{b}=\frac{\left(\varrho_{b c}-\varrho_{f c}\right)\left(\varrho_{g}-\varrho_{f}\right)}{\left(\varrho_{g c}-\varrho_{f c}\right)}+\varrho_{f},
$$

where $\varrho_{g}=$ true grain density $\left(\simeq 2.7 \mathrm{Mg} / \mathrm{m}^{3}\right.$ for sediments, although actual grain densities were determined subsequently to range from 2.41 to $2.43 \mathrm{Mg} / \mathrm{m}^{3}$ ); $\varrho_{g c}=$ corrected grain density $\left(\simeq 2.7 \mathrm{Mg} / \mathrm{m}^{3}\right.$ for sediments); $\varrho_{f}=$ true fluid density $\left(\simeq 1.025 \mathrm{Mg} / \mathrm{m}^{3}\right) ; \varrho_{f c}=$ corrected fluid density $\left(\simeq 1.128 \mathrm{Mg} / \mathrm{m}^{3}\right)$; and $\varrho_{b}=$ true wet-bulk density.

Using these values,

$$
\varrho_{b}=1.066\left(\varrho_{b c}-1.128\right)+1.025 .
$$

If the sample did not fill the core, then corrections were made, depending on the diameter of the rock core and on the nature of the materials surrounding the core (air, water, sediment, or breccias). Then,

$$
\varrho_{b c}=\frac{100 \varrho_{b c z}-S x}{100-x}
$$


where $S=$ "corrected" wet-bulk density of the material around the core and

$$
X=100 \cdot\left[\frac{6.61 \mathrm{~cm}-(\text { gamma ray path length, in } \mathrm{cm})}{6.61 \mathrm{~cm}}\right] .
$$

Values for $S$ were: $S=0.0 \mathrm{Mg} / \mathrm{m}^{3}$ for air, $S=1.1$ $\mathrm{Mg} / \mathrm{m}^{3}$ for water, $S=1.4 \mathrm{Mg} / \mathrm{m}^{3}$ for sediment slurry, and $S=1.8 \mathrm{Mg} / \mathrm{m}^{3}$ for drilling breccia. For lack of any method of determining whether or not an undersized core was aligned with the beam, the gamma ray path length was assumed to equal the core diameter.

Shipboard reduction of analog GRAPE records involved (1) selection of high-density portions of each core section on the analog record; (2) determination from core photographs of core diameter and composition of material around the core; and (3) calculation of true wet-bulk density $\left(\varrho_{b}\right)$ by formulas (1), (2), and (3). The $\varrho_{b c}$ determined by equation (2) is used in equation (1) to calculate $\varrho_{b}$. The porosity $\phi$ is obtained by

$$
\phi(\%)=\frac{\varrho_{g}-\varrho_{b}}{\varrho_{g}-\varrho_{f}} \times 100 .
$$

\section{Two-Minute GRAPE}

For two-minute GRAPE calculations,

$$
\varrho_{b c}=\frac{\ln \left(\mathrm{I}_{o} / \mathrm{I}\right)}{d \mu q t z}
$$

where $\mathrm{I}_{o}=$ two-minute gamma count through air, $\mathrm{I}=$ two-minute gamma count through the sample, $d=$ gamma ray path length through the sample, and $\mu q t z=$ quartz attenuation coefficient determined daily by measuring through a quartz standard. Then, as in the continuous GRAPE calculation (assuming a $2.7 \mathrm{Mg} / \mathrm{m}^{3}$ grain density),

$$
\varrho_{b}=1.066\left(\varrho_{b c}-1.128\right)+1.025
$$

and

$$
\phi(\%)=\frac{100\left(2.70-\varrho_{b}\right)}{1.675}
$$

Boyce (1976) estimates $\pm 5 \%$ accuracy for continuous GRAPE data and $\pm 2 \%$ for two-minute GRAPE data. In practice, it was found that the error on Leg 67 determinations seemed to be higher, owing in part to the highly disturbed nature of many of the cores and in part to errors in gamma ray travel path determinations due to the extremely friable nature of the sediments. However, good agreement exists between the GRAPE data from selected portions (as just described) of nearly every section and the gravimetric methods (syringe and rock chunk).

\section{Gravimetric Technique: Syringe and Rock Chunk}

In a soft sediment (recovered to a sub-bottom depth of $\leqslant 50 \mathrm{~m}$ ), a $1-\mathrm{cm}^{3}$ syringe was used to collect a mea- sured volume of sample for on-board analysis. In harder sediments (and in the majority of all cores), a 20- to $50-\mathrm{cm}^{3}$ chunk of material was collected. A small piece of this chunk was used for water content determination only; the remainder was used for a volume determination by immersion in water; wet-bulk density, porosity, and water content were then determined. No salt corrections were applied in any of these techniques. Drying and weighing facilities were present on board for carrying out these measurements.

$$
\text { Water content (percent net weight) }=
$$

$100 \times \frac{[\text { (weight wet sediment) }- \text { (weight dry sediment) }]}{\text { (weight wet sediment) }}$.

Wet-bulk density $\left(\mathrm{Mg} / \mathrm{m}^{3}\right)=\frac{\text { weight of wet sediment }}{\text { volume of wet sediment }}$.

The $1-\mathrm{cm}^{3}$ syringe samples provided a volume measurement. However, Bennett and Keller (1973) note that the volume is actually too small for accurate determinations. The method is also highly dependent on sampling techniques; any cracks or voids in the sample lead to large inaccuracies. In addition, despite all precautions, some compression of the sample was noted in almost all samples taken during the cruise, thus leading to inaccuracies in the volume measurement. Large samples taken for shore-based determinations provide much more accurate results.

The syringe and rock-chunk methods also give the porosity as follows:

$$
\text { Porosity }(\%)-100 \times \frac{\text { weight of evaporated water }}{\text { volume of wet sediment }} \text {. }
$$

In general, the gravimetric techniques give useful data for comparison with the GRAPE data, and when good sampling techniques are followed (and good samples are available) the data generally compare well.

\section{Vane Shear}

A CL-600 Torvane was used on board to determine the undrained shear strength of clayey sediments. The Torvane was hand-rotated at a rate designed to reach failure in about $10 \mathrm{~s}$ with constant loading. All of these measurements for Leg 67 were made by the same person. Repeated determinations yielded results that were generally reproducible to $\pm 15 \%$. Measurements were made in the least-disturbed sections of the core on horizontal surfaces. Measurements were discontinued when cracking of the sediments was observed, indicating failure by fracturing rather than by shear.

\section{Obtaining Samples}

Potential investigators who desire to obtain samples should refer to the DSDP-NSF Sample Distribution Policy (see the Table of Contents). Sample request forms may be obtained from The Curator, Deep Sea Drilling Project, A-031, University of California, San Diego, La Jolla, California 92093. Requests must be as specific as 
possible: include site, core, section, interval within a section, and volume of samples required.

\section{Numbering of Sites, Holes, Cores, and Samples}

DSDP drill sites are numbered consecutively from the first site drilled by Glomar Challenger in 1968. Site numbers are slightly different from hole numbers. A site number refers to one or more holes drilled while the ship was positioned over one acoustic beacon; these holes could be located within a radius as great as 900 meters from the beacon. Several holes may be drilled at a single site by pulling the drill pipe above the seafloor (out of one hole), moving the ship 100 meters or more from the previous hole, and then drilling another hole.

The first (or only) hole drilled at a site takes the site number. A letter suffix distinguishes each additional hole at the same site. For example, the first hole takes only the site number, the second takes the site number with suffix $A$, the third takes the site number with suffix $\mathrm{B}$, and so forth. It is important, for sampling purposes, to distinguish the holes drilled at a site, because recovered sediments or rocks from different holes usually do not come from equivalent positions in the stratigraphic column.

The cored interval is measured in meters below the seafloor. The depth interval of an individual core is the depth below seafloor that the coring operation began to the depth that the coring operation ended. Each coring interval is generally 9.5 meters long, which is the nominal length of a core barrel; however, the coring interval may be shorter or sometimes slightly longer. Cored intervals are not necessarily adjacent to each other, but may be separated by drilled intervals. In soft sediment the drill string can be "washed ahead," with the core barrel in place but not recovering sediment, by pumping water down the pipe at high pressure to wash the sediment out of the way of the bit and up the space between the drill pipe and wall of the hole. However, if thin, hard rock layers are present, then it is possible to get "spotty" sampling of these resistant layers within the washed interval, and thus have a cored interval greater than 9.5 meters.

Cores taken from a hole are numbered serially from the top of the hole downward. Core numbers and their associated cored interval in meters below the seafloor are normally unique for a hole, however, problems may arise if an interval is cored twice.

Full recovery for a single core is normally 9.28 meters of sediment or rock, which is in a plastic liner $(6.6 \mathrm{~cm}$, I.D.), plus about a 0.2 meter-long sample (without a plastic liner) in the core-catcher. (The core catcher is a device at the bottom of the core barrel that prevents the cored sample from sliding out when the barrel is being retrieved from the hole.) The core is then cut into 1.5meter-long sections and numbered serially from the top of the core (Fig. 9). When there is full recovery, the sections are numbered from 1 through 9 with the last section shorter than 1.5 meters. The core-catcher sample is placed below the last section when the core is described, and labeled core catcher (CC); it is treated as a separate section.

In the case of partial recovery, the original stratigraphic position of the sediment in the cored interval is unknown. If the recovered rock and sediment is contiguous, we assign the top of this material to the top of the cored interval and number sections serially from the top beginning with Section 1 (Fig. 9). There are as many sections as needed to accommodate the length of the recovered sediment. For example, 4 meters of sediment are divided into three sections, two upper sections each 1.5 meters long and a final lower section only 1.0 meters in length. If the sediment recovered is not contiguous, as determined by the shipboard scientists, then sections are divided and numbered serially, as with continuous material, and gaps labeled as voids for sediments (Fig. 9) or marked by spacers for igneous rocks (see the section on Igneous Rocks).

Samples are designated by centimeter distances from the top of each section to the top and bottom of the sample in that section. A full identification number for a sample consists of the following information: leg-sitehole-core number-section number, interval in centimeters from the top of the section. For example, a sample identification number of $67-494 \mathrm{~A}-9-3,12-14 \mathrm{~cm}$ is interpreted as follows: $12-14 \mathrm{~cm}$ designates a sample taken at $12-14 \mathrm{~cm}$ from the top of Section 3 of Core 9, from the second hole drilled at Site 494 during Leg 67. A sample from the core catcher of this core is designated as $67-494-9, \mathrm{CC}$.

\section{Handling of Cores}

A core is normally cut into 1.5 -meter sections, sealed, labeled, and then brought into the core laboratory for processing. Gas analyses and continuous wet-bulk density determinations using the Gamma Ray Attenuation Porosity Evaluator (GRAPE) are made on selected sections before splitting the plastic liner.

The cores are then split longitudinally into "working" and "archive" halves. Samples are taken from the "working" half, including those for determination of grain-size distribution, mineralogy by X-ray diffraction, sonic velocity by the Hamilton Frame method, wet-bulk density by a static GRAPE technique, water content by gravimetric analysis, carbon-carbonate analysis, calcium-carbonate percentage (Karbonate Bombe), geochemical analysis, paleontological studies, and others.

Smear slides (thin sections for lithified sedimentary and igneous rocks) from each major lithology, and most minor lithologies, are prepared and examined microscopically. The archive half is then described and photographed. Physical disturbance caused by the drill bit, color, texture, structures, and composition of the various lithologies are noted on standard core description forms (Fig. 10). All prime data are routinely microfilmed, and some are digitized for computer retrieval.

After the cores are sampled and described, they are maintained in cold storage aboard Glomar Challenger until they can be transferred to the DSDP Repository. 

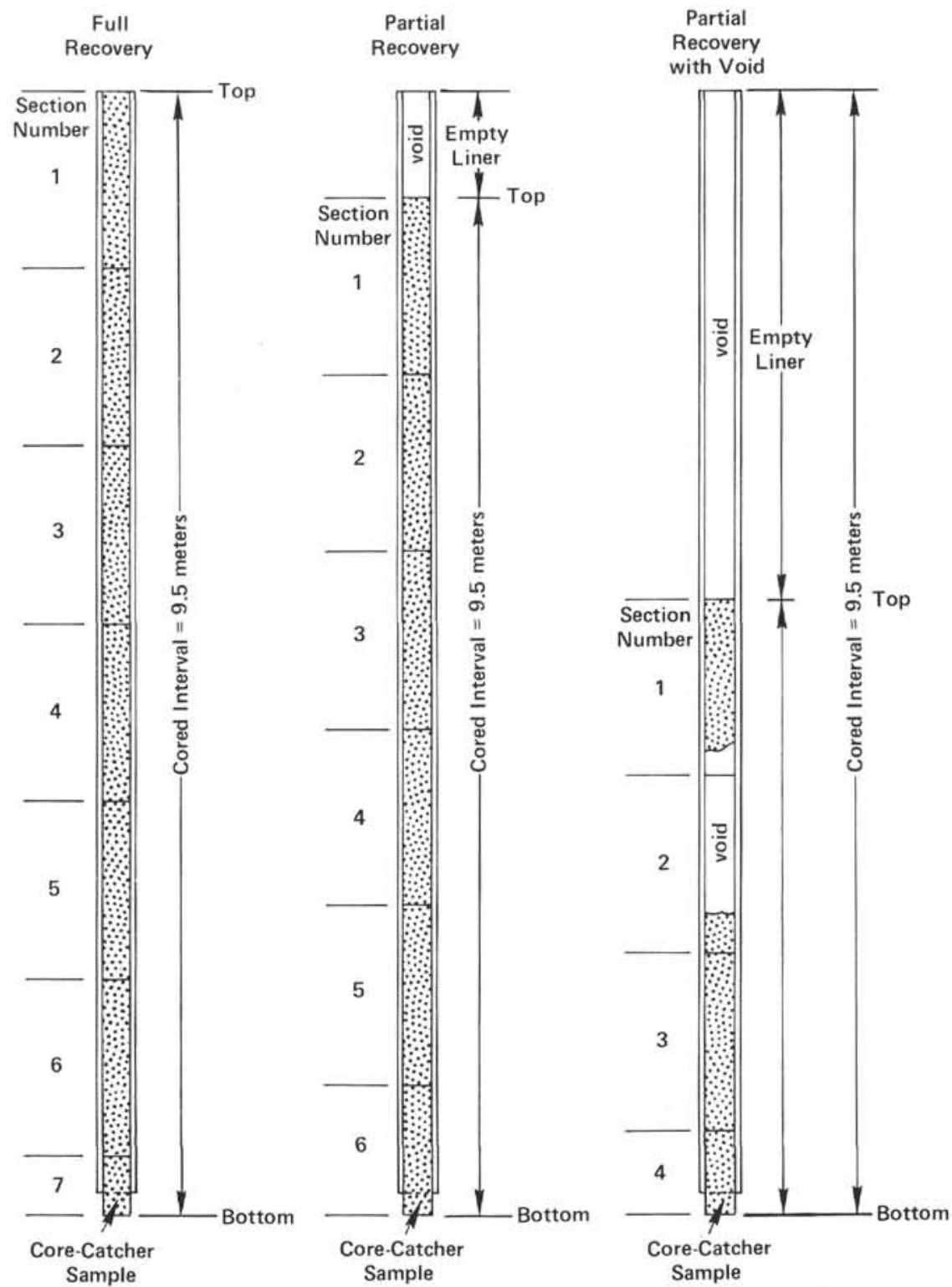

Figure 9. Conventions in cutting and labeling of Leg 67 core sections.

Core sections of sediments removed for organic geochemistry study are frozen immediately aboard ship and kept frozen. All Leg 67 cores are presently stored at the DSDP West Coast Repository (Scripps Institution of Oceanography).

\section{Visual Descriptions}

\section{Sediment Disturbance}

Recovered rocks, and particularly the soft sediments, may be extremely disturbed. This mechanical disturbance is the result of the coring technique, which uses a large $25-\mathrm{cm}$-diameter bit with a small 6.0 -cm-diameter opening for the core sample. The following disturbance categories are used for soft and firm sediments:

Slightly deformed: bedding contacts are slightly bent.

Moderately deformed: bedding contacts have undergone extreme bowing; firm sediment is fractured.
Very deformed: bedding is completely disturbed or homogenized by drilling, sometimes showing symmetrical diapirlike structure; firm zones may have relic "drill biscuits" in a breccia or homogeneous matrix.

Soupy: water-saturated intervals that have lost all aspects of original bedding.

Breccia: indurated sediments broken into angular fragments by the drilling process, perhaps along preexisting fractures.

These categories are coded on the core description form in the "Drilling Disturbance" column (Fig. 10).

\section{Sedimentary Structures}

In the soft, and even in some harder, sedimentary cores, it may be extremely difficult to distinguish between natural structures and those created by the coring process. Thus the description of sedimentary structures was optional. Locations and types of these structures 


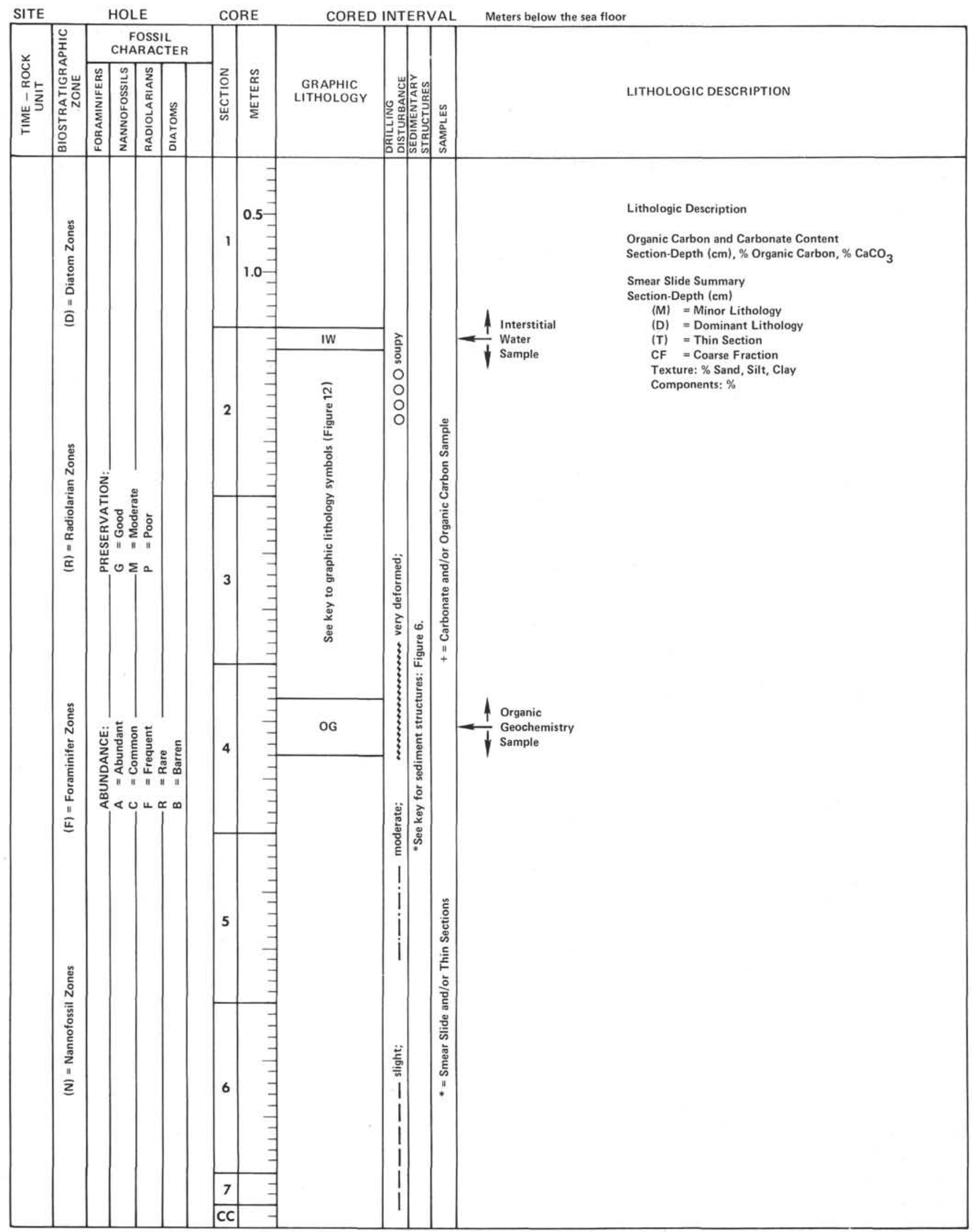

Figure 10. Sample core description form. 
appear as graphic symbols in the column headed "Sedimentary Structures"' on the core description form (Fig. 10). Figures 11 and 12 give the keys to these symbols.

\section{Color}

Colors of the core samples are determined with a Geological Society of America Rock-Color Chart. Colors were determined immediately after the cores were split and while wet.

\section{Graphic Lithology}

The "Graphic Lithology" column presented on the core description form is based on the lithologies and represented by a single pattern or by a grouping of two or more symbols. The symbols in a grouping correspond to end members of sediment constituents, such as clay or nannofossil ooze. The symbol for the terrigenous constituent appears on the right-hand side of the column, the symbol for the biogenic constituent(s) is on the left-hand side of the column. The abundance of any component approximately equals the percentage of the width of the graphic column its symbol occupies. For example the left $20 \%$ of the column may have a diatom ooze symbol, whereas the right $80 \%$ of the column may have a silty-clay symbol, indicating sediment composed of $80 \%$ mud and $20 \%$ diatoms.

Because of the difference in the length-to-width ratio between the actual sediment core and the "Graphic Li-

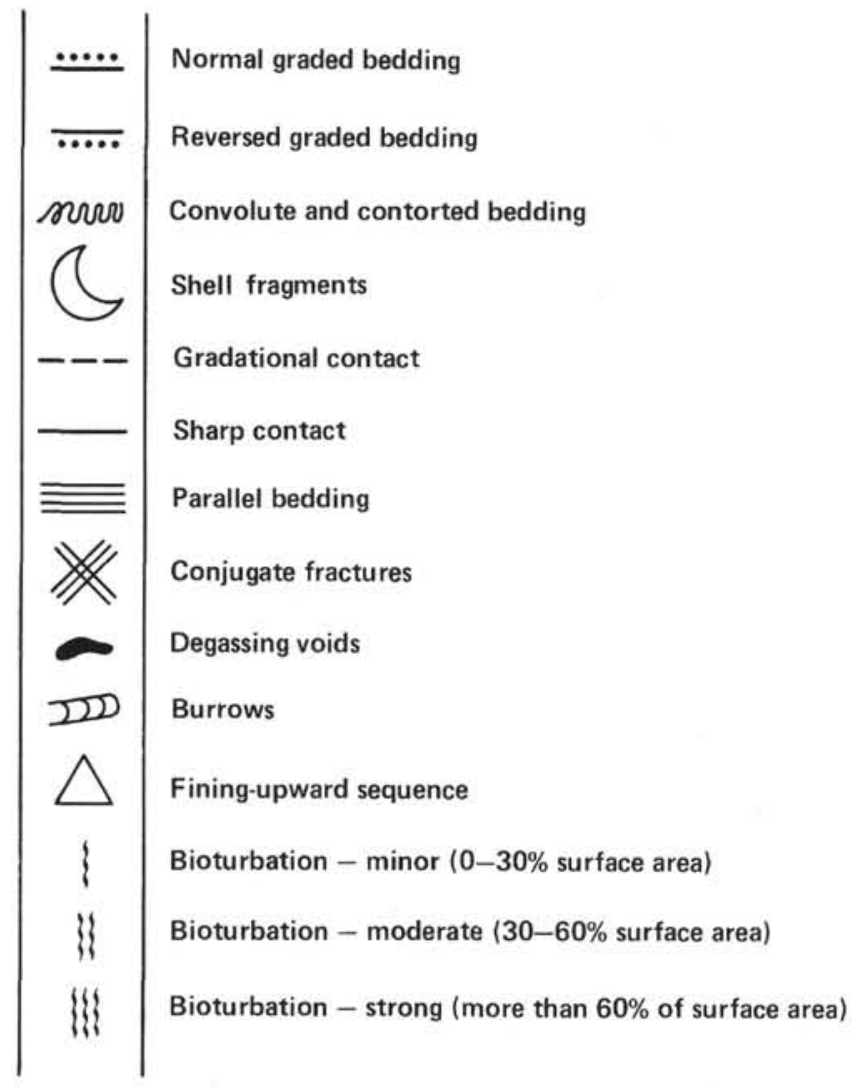

Figure 11. Symbols used in the "Sedimentary Structures" column of the core description form. thology"' column, it is not possible to reproduce structures as they appeared in the core; they become highly flattened and distorted. The same is true for rock fragments or pebbles in the cores. This convention applies also to beds thinner than $10 \mathrm{~cm}$. Voids less than $10 \mathrm{~cm}$ are not shown; there are many of these in Leg 67 cores.

Smear slides (or thin-section) compositions, carbonate content $\left(\% \mathrm{CaCO}_{3}\right)$, and organic carbon content determined aboard ship are listed below the core description on these forms, where two numbers separated by a hyphen refer to the section and centimeter interval, respectively, of the sample. The locations of these samples in the core and a key to the codes used to identify these samples are given in the column headed "Samples" (Fig. 10). Locations and intervals of organic geochemistry (OG), interstitial water (IW), and physical property (BRY) samples are given in the lithology column.

\section{Igneous Rocks}

\section{Visual Core Description Forms}

All igneous rocks were split into working and archive halves using a rock saw and were described and sampled on board ship. Figure 13 shows a composite visual core description form used for the description of igneous rocks recovered on Leg 67 . On this form, each section of a core is described under a set of five column headings: "Piece Number,", "Graphic Representation,", "Orientation," "'Shipboard Studies,", and "Alteration."

In the "Graphic Representation"' column, each piece is accurately drawn and different features (such as texture, glassy margins, or vesicles) coded according to the symbols given in Figure 14. Two closely spaced horizontal lines in this column indicate the location of styrofoam spacers taped between pieces inside the liner. Each piece is numbered sequentially from the top of the section beginning with the number 1 (in the "Piece Number"' column). Pieces are labeled on the rounded surface rather than the flat, slabbed face. Pieces that fit together before splitting were given the same number, but are consecutively lettered as $1 \mathrm{~A}, 1 \mathrm{~B}, 1 \mathrm{C}$, etc. Spacers were placed only between pieces that did not fit together; those pieces were given different numbers. In general, spacers may or may not indicate missing core (not recovered) between pieces. All cylindrical pieces longer than the diameter of the liner have arrows in the "Orientation"' column indicating that top and bottom have not been reversed as a result of drilling and recovery. Arrows also appear on the labels of these pieces on both archive and working halves.

The column marked "Shipboard Studies" designates the location and the type of measurements made on a sample aboard ship. The column headed "Alteration" gives the degree of alteration, using the code provided in Figure 14. Below each set of five descriptive columns is the designation for core and section for which these data apply.

Figure 13 shows the outline for core descriptions of igneous rocks in the right-hand margin of the visual core description form. If more than one core appear on the 


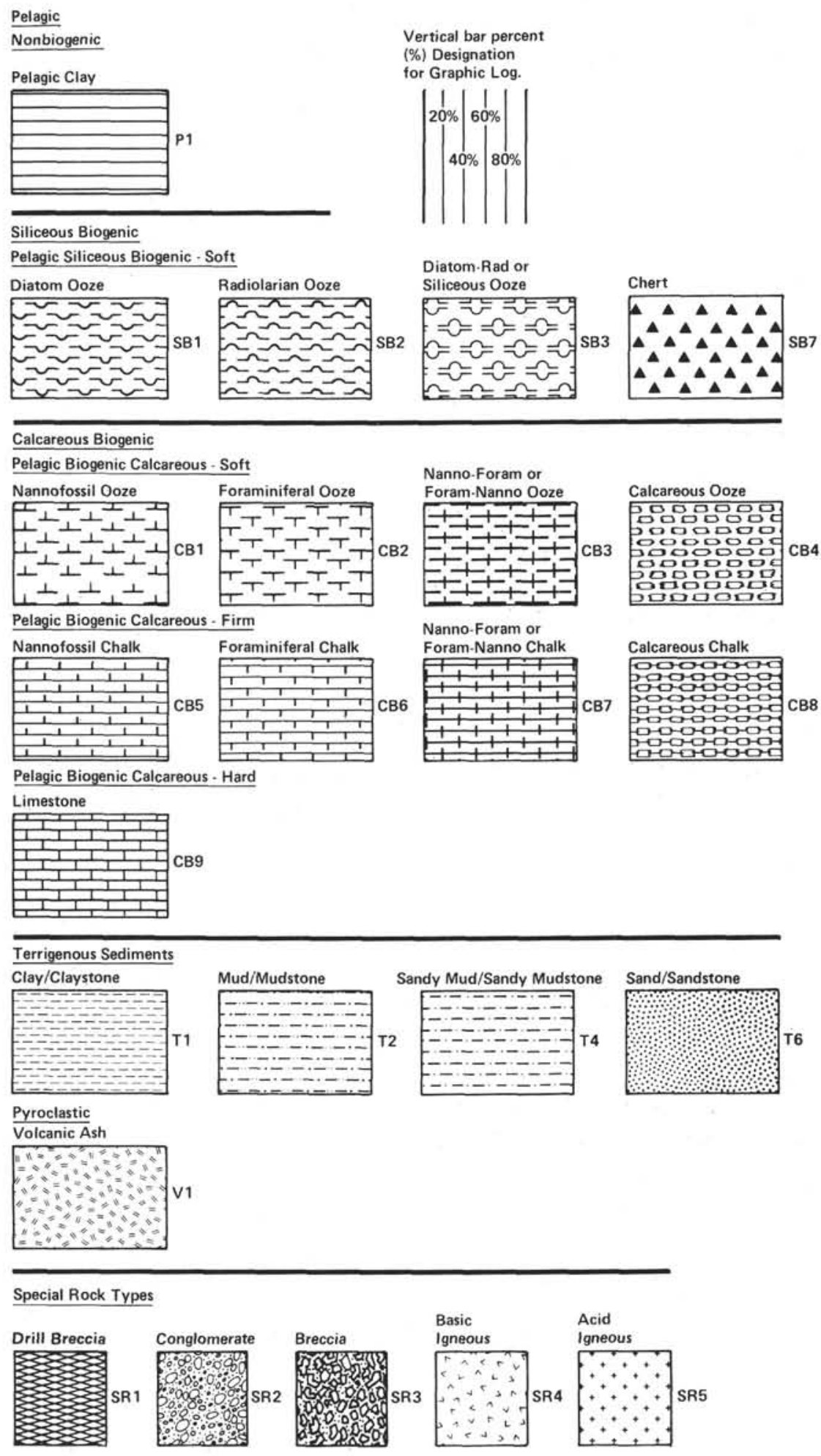

Figure 12. Symbols used in the "Graphic Lithology" column of the core description form.

core form, these data are listed below the description of the first core using the same format. As many cores as space allows for are included on one visual core description form. When space for descriptions is inadequate on this form, these data appear on the following or facing page. However, in no case does information from one core appear on successive core forms.
For each core, the core number, section, and depth interval recovered are listed followed by the major and minor rock types and a short description.

\section{REFERENCES}

Arthur, M. A., Carson, B., and von Huene, R., 1980. Initial tectonic deformation of hemipelagic sediment of the leading edge of the Ja- 
pan convergent margin. In Scientific Party, Init. Repts. DSDP, 56, 57, Pt. 1: Washington (U.S. Govt. Printing Office), 569-613.

Beck, R. H., and Lehner, P., 1974. Oceans, new frontier in exploration. Am. Assoc. Pet. Geol. Bull., 58:376-395.

Beckmann, J., 1953. Die Foraminiferan der Oceanic Formation (Eocaen-Oligocaen) von Barbados, Kl. Antillen. Eclogae Geol. Helv., 46:301-412.

Bennett, R. H., and Keller, G., 1973. Physical properties evaluation. In van Andel, $\mathrm{Tj}$. H., Heath, G. R., et al., Init. Repts. DSDP, 16: Washington (U.S. Govt. Printing Office), 513-519.

Berger, W. H., and Winterer, E. L., 1974. Plate stratigraphy and the fluctuating carbonate line. In Hsü, K. J., and Jenkyns, H. C. (Eds.), Pelagic Sediments: On Land and Under the Sea: Oxford (Blackwell Scientific Publications), pp. 11-48.

Berggren, W. A., 1973. The Pliocene time-scale: calibration of planktonic, foraminiferal, and calcareous nannoplankton zones. $\mathrm{Na}$ ture, 243:391-397.

Berggren, W. A., and Van Couvering, J. A., 1974. The Late Neogene: Amsterdam (Elsevier).

Blow, W. H., 1969. Late middle Eocene to Recent planktonic foraminiferal biostratigraphy. In Bronniman, P. and Renz, H. H. (Eds.), Proceedings of the First International Conference on Planktonic Microfossils: Leiden (E. J. Brill), pp. 199-421.

Boyce, R. E., 1976. Definitions and laboratory techniques of compressional sound velocity parameters and wet-water content, wet-bulk density, and porosity parameters by gravimetric and gamma ray attenuation techniques. In Schlager, S. O., Jackson, E. D., et al., Init. Reports. DSDP, 33: Washington (U.S. Govt. Printing Office), 931-935.

Bukry, D., 1975. Coccolith and silicoflagellate stratigraphy, northwestern Pacific Ocean. In Larson, R. L., Moberly, R., et al., Init. Reports DSDP, 32: Washington (U.S. Govt. Printing Office), 677-701.

Coulbourn, W. T., 1981. Tectonics of the Nazca Plate edge and the continental margin of western South America, $18-23^{\circ} \mathrm{S}$ latitude. In Kulm, L. D., Dymond, J., Dasch, J. E., Hussong, D. M., and Roderick, R. (Eds.), The Nazca Plate and Adjacent Southern American Margin: Ann Arbor (Geol. Soc. Am. Mem. 154), pp. 587-618.

Coulbourn, W. T., and Moberly, R., 1977. Structural evidence for the evolution of fore-arc basins off South America. Can. J. Earth Sci., $14: 102-116$

Creager, J. S., Scholl, D. W., et al., 1973. Init, Repts. DSDP, 19: Washington (U.S. Govt. Printing Office), 217-284.

Dean, B. W., and Drake, C. L., 1978. Focal mechanism solutions and tectonics of the Middle America Arc. J. Geol, 86:111-128.

Den, N., and Yoshii, T., 1970. Crustal structure of Tosa Deep-Sea Terrace and Nankai Trough. Pt. 2. Interpretations (in Japanese with English abstract). In Hosino, M., and Aoki, H. (Eds.), Island Arc and Ocean: Tokyo (Tokai University Press), pp. 95-100.

Dickinson, W. R., and Seely, D. R., 1979. Structure and stratigraphy of forearc regions. Am. Assoc. Pet. Geol. Bull., 63:2-31.

Gealy, E. L., Winterer, E. L., and Moberly, R., 1971. Methods, conventions, and general observations. In Winterer, E. L., Riedel, W. R., et al., Init. Reports. DSDP, 7, Pt. 2: Washington (U.S. Govt. Printing Office), 9-26.

Grow, J. A., 1973. Implications of deep sea drilling. Sites 186 and 187 on island arc structure. In Creager, J. S., Scholl, D. W., et al., Init. Repts. DSDP, 19: Washington (U.S. Govt. Printing Office), 799-803.

Hamilton, W., 1977. Subduction in the Indonesian region. In Talwani, M., and Pitman, W. C., III (Eds.), Island Arcs, Deep Sea Trenches, and Back-arc Basins: Washington (Am. Geophys. Union, Maurice Ewing Ser. 1), pp. 15-31.

Hanks, T. C., 1971. The Kuril-Hokkaido Rise system: large shallow earthquakes and simple models of deformation. Geophys. J. R. Astron. Soc, , 23:173-189.

Helwig, J., and Hall, G. A., 1974. Steady-state trenches? Geology, 2:309-316.

Hussong, D. M., Edwards, P. B., Johnson, S. H., Campbell, J. F., and Sutton, G. H., 1976. Crustal structure of the Peru-Chile Trench: $8^{\circ}-12^{\circ} \mathrm{S}$ latitude. In Sutton, G. H., Manghnani, M. H., Moberly, R., and McAfee, E. U., (Eds.), The Geophysics of the Pacific Ocean Basin and Its Margin: A Volume in Honor of
George P. Wollard: Washington (Am. Geophys. Union Geophysical Monograph 19), 19:71-86.

Hussong, D. M., and Uyeda, S. 1981. Tectonic processes and the history of the Mariana Arc: A synthesis of the results of Deep Sea Drilling Project Leg 60. In Hussong, D. M., Uyeda, S., et al., Init. Repts. DSDP, 60: Washington (U.S. Govt. Printing Office), 909-929.

Hussong, D. M., and Wipperman, L. K. 1981. Vertical movement and tectonic erosion of the continental wall of the Peru-Chile Trench near $11^{\circ} 30^{\prime}$ S latitude. In Kulm, L. D., Dymond, J., Dach, J. E., Hussong, D. M., and Roderick, R. (Eds.), Nazca Plate: Crustal Formation and Andean Convergence: Ann Arbor (Geol. Soc. Am. Mem. 154), pp. 509-524.

Ibrahim, A. K., Latham, G. V., and Ladd, J., 1979. Seismic refraction and reflection measurements in the Middle America Trench offshore Guatemala. J. Geophys. Res., 84(B10):5643-5649.

Jenkins, D. G., and Orr, W. N., 1972. Planktonic foraminiferal biostratigraphy of the Eastern Equatorial Pacific. In Hays, J. D., et al., Init. Repts. DSDP, 9: Washington (U.S. Govt. Printing Office), 1059-1196.

Kaizuka, S., Matsuda, T., Nogami, M., and Yonekra, N., 1973. Quaternary tectonic and Recent seismic crustal movements in the Arauco Peninsula and its environs, Central Chile. Geographical Reports of Tokyo Metropolitan Univ., 8:1-49.

Karig, D. E., Cardwell, R. K., Moore, G. F., and Moore, D. G., 1978. Late Cenozoic subduction and continental margin truncation along the northern Middle America Trench. Geol. Soc. Am. Bull., $89: 265-276$.

Karig, D. E., Ingle, J. C., Jr., et al., 1975. Site 298. In Karig, D. E., Ingle, J. C., Jr., et al., Init. Repts. DSDP, 31: Washington (U.S. Govt. Printing Office), 317-332.

Karig, D. E., and Sharman, G. F., 1975. Subduction and accretion in trenches. Geol. Soc. Am. Bull., 86:377-389.

Kulm, L. D., Resig, J. M., Moore, T. C., and Rosato, V. J., 1974. Transfer of Nazca Ridge pelagic sediments to the Peru continental margin. Geol. Soc. Am. Bull., 85:769-780.

Kulm, L. D., von Huene, R., et al., 1973. Sites 175, 181 and 182. In Kulm, L. D., von Huene, R., et al., Init. Repts. DSDP, 18: Washington (U.S. Govt. Printing Office), 169-212 and 499-513.

Ladd, J. W., Ibrahim, A. K., McMillen, K. J., Latham, G. V., von Huene, R. E., Watkins, J. S., Moore, J. C., and Worzel, J. L., 1978. Tectonics of the Middle America Trench. Int. Symp. Guatemalan Earthquake and Reconstruction Process, Feb. 4th, 1976, Vol. 1, Guatemala City.

Ladd, J. W., and Watkins, J. S., 1979. Tectonic development of trencharc complexes on the northern and southern margins of the Venezuela Basin. In Watkins, J. S., Montadert, L., and Dickerson, P. W. (Eds.), Geological and Geophysical Investigations of Continental Margins: Tulsa (Am. Assoc. Pet. Geol. Mem. 29), pp. 363-371.

Le Quellec, P., Mascle, J., Got, H., and Vittori, J., 1980. Seismic structure of southwestern Peloponnesus continental margin. Am. Assoc. Pet. Geol. Bull., 64:242-263.

Montecchi, P. A., 1976. Some shallow tectonic consequences of subduction and their meaning to the hydrocarbon explorationist. In Halbouty, M. T., Maher, J. C., and Lian, H. M. (Eds.), CircumPacific Energy and Mineral Resources: Tulsa (Am. Assoc. Pet. Geol. Mem. 25), pp. 189-202.

Moore, G. F., Billman, H. G., Hehanussa, P. E., and Karig, D. E., 1980. Sedimentology and paleobathymetry of Neogene trench-slope deposits, Nias Island, Indonesia. J. Geol., 88:161-180.

Moore, G. F., and Karig, D. E., 1976. Development of sedimentary basins on the lower trench slope. Geology, 4:693-697.

1980. Structural geology of Nias Island, Indonesia: implications for subduction zone tectonics. Am. J. Sci., 280:193-223.

Moore, J. C., Watkins, J. S., Shipley, T. H., Bachman, S. B., Beghtel, F. W., Butt, A., Didyk, B. M., Leggett, J. K., Lundberg, N., McMillen, K. J., Niitsuma, N., Shephard, L. E., Stephan, J., and Stradner, H., 1979. Progressive accretion in the Middle America Trench, Southern Mexico. Nature, 281:638-642.

Nigrini, C. A., 1971. Radiolarian zones in the Quaternary of the Equatorial Pacific Ocean. In Funnell, B. M., and Riedel, W. R. (Eds.), The Micropalaontology of Oceans: New York (Cambridge Univ. Press), pp. 443-460. 
Prince, R. A., and Kulm, L. D., 1975. Crustal rupture and the initiation of imbricate thrusting in the Peru-Chile Trench. Geol. Soc. Am. Bull., 86:1639-1653.

Riedel, W. R., and Sanfilippo, A., 1978. Stratigraphy and evolution of tropical Cenozoic radiolarians. Micropaleontology, 20:52.

Ross, D. A., and Shor, G. G., 1965. Reflection profiles across the Middle America Trench. J. Geophys. Res., 70:5551-5572.

Ryan, W. B. F., Hsü, K. J., et al., 1973. Sites 127 and 128. In Ryan, W. B. F., Hsü, K. J., et al. Init. Repts. DSDP, 13, Pt. 1: Washington (U.S. Govt. Printing Office), 243-322.

Scholl, D. W., and Marlow, M. S., 1974. Global tectonics and sediments of modern and ancient trenches: some different interpretations. In Kahle, C. F. (Ed.), Plate Tectonics Assessments and Reassessments: Tulsa (Am. Assoc. Pet. Geol., Mem. 23), pp. 255-272.

Scholl, D. W., Marlow, M. S., and Cooper, A. K., 1977. Sediment subduction and offscraping at Pacific margins. In Talwani, M., and Pitman, W. C., III (Eds.), Island-Arcs, Deep Sea Trenches, and Back-Arc Basins: Washington (Am. Geophys. Union, Maurice Ewing Ser. 1), pp. 199-210.

Scientific Party, 1980. Init. Repts. DSDP, 56, 57: Washington (U.S. Govt. Printing Office).

Scientists aboard the Glomar Challenger, 1978a. Transects begun. Geotimes, 23 March:22-26.

, 1978b. Japan Trench transected. Geotimes, 23 April: 16-21. , 1978c. Leg 60 ends in Guam. Geotimes, 23 October:19-22. , 1979. Middle America Trench drilled. Geotimes, 24 September:20-22.

Seely, D. R., 1979. The evolution of structural highs bordering major forearc basins. In Watkins, J. S., Montadert, L., and Dickerson, P. W. (Eds.), Geophysical Investigations of Continental Slopes and Rises: Tulsa (Am. Assoc. Pet. Geol., Mem. 29), pp. 245-260.

Seely, D. R., Vail, P. R., and Walton, G. G., 1974. Trench-slope model. In Burk, C. A., and Drake, C. L. (Eds.), The Geology of Continental Margins: New York (Springer-Verlag), pp. 249-260.
Shipley, T. H., McMillen, K. J., Watkins, J. S., Moore, J. C., Sandoval-Ochoa, J. H., and Worzel, J. L., 1980. Continental margin and lower slope structures of the Middle America Trench near Acapulco (Mexico). Mar. Geol., 35:65-82.

Silver, E. A., 1971. Transitional tectonics and late Cenozoic structure of the continental margin off northernmost California. Geol. Soc. Am. Bull., 82:1-22.

Speed, R. C., 1978. Barbados: structural analysis of early Tertiary rocks. Geol. Soc. Am.: Absts. with Prog., 10:496. (Abstract)

Theyer, F., 1974. Cenozoic magnetic time scale in deep sea cores: completion of the Neogene. Geology, 2:487-492.

Theyer, F., and Hammond, S. R., 1974. Paleomagnetic polarity sequence and radiolarian zones, Brunhes to polarity Epoch 20. Earth Planet. Sci. Lett., 22:307-319.

Theyer, F., Mato, C. Y., and Hammond, S. R., 1978. Paleomagnetic and geochronologic calibration of latest Oligocene to Pliocene radiolarian events, equatorial Pacific. Mar. Micropaleontol., 3: 377-395.

von Huene, R., Aubouin, J., Azema, J., Blackinton, G., Carter, J. A., Coulbourn, W. T., Cowan, D. S., Curiale, J. A., Dengo, C. A., Faas, R. W., Harrison, W., Hesse, R., Hussong, D. M., Ladd, J. W., Muzylöv, N., Shiki, T., Thompson, P. R., and Westberg, J., 1980. Leg 67: The Deep Sea Drilling Project Mid-America Trench transect off Guatemala. Geol. Soc. Am. Bull., 91(1):421-432.

Wentworth, C. K., 1922. A scale of grade and class terms of clastic sediments. J. Geol., 30:377.

Wentworth, C. K., and Williams, H., 1932. The classification and terminology of the pyroclastic rocks. Nat. Res. Counc. Bull., 89; 19-53.

White, R. S., and Klitgord, K., 1976. Sediment deformation and plate tectonics in the Gulf of Oman. Earth Planet. Sci. Lett., 32: 199-209. 


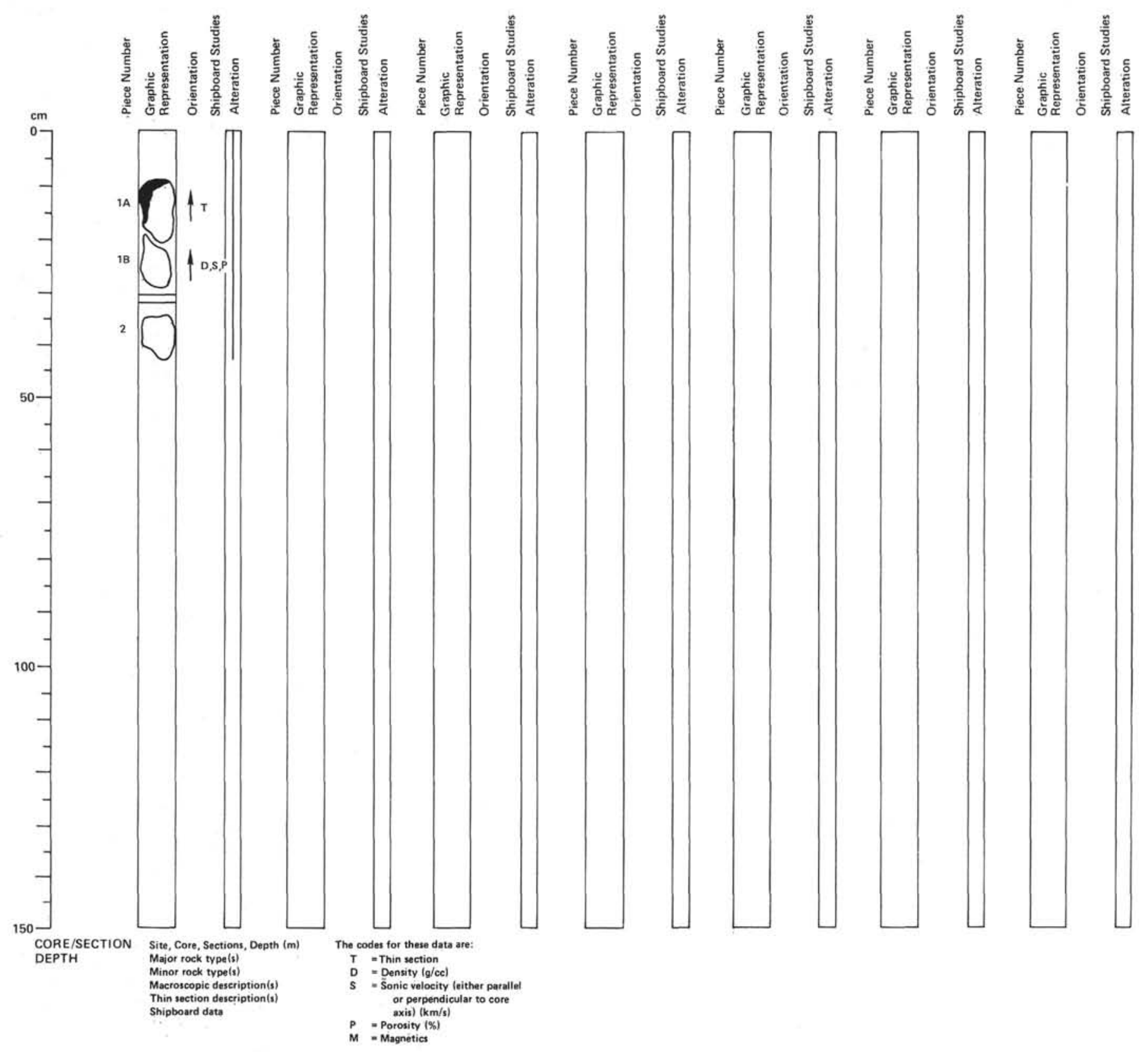

Figure 13. Visual core description form for igneous rocks. 
Texture:

(used in graphic representation column)

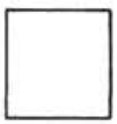

Aphyric basalt

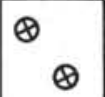

Variolitic basalt

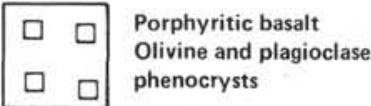 $\square \times \quad \begin{aligned} & \text { Olivine, plagioclase, } \\ & \text { and clinopyroxene }\end{aligned}$
$\square \times$ phenocrysts

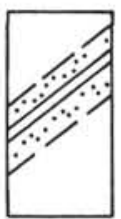

Vein with altered zone next to it
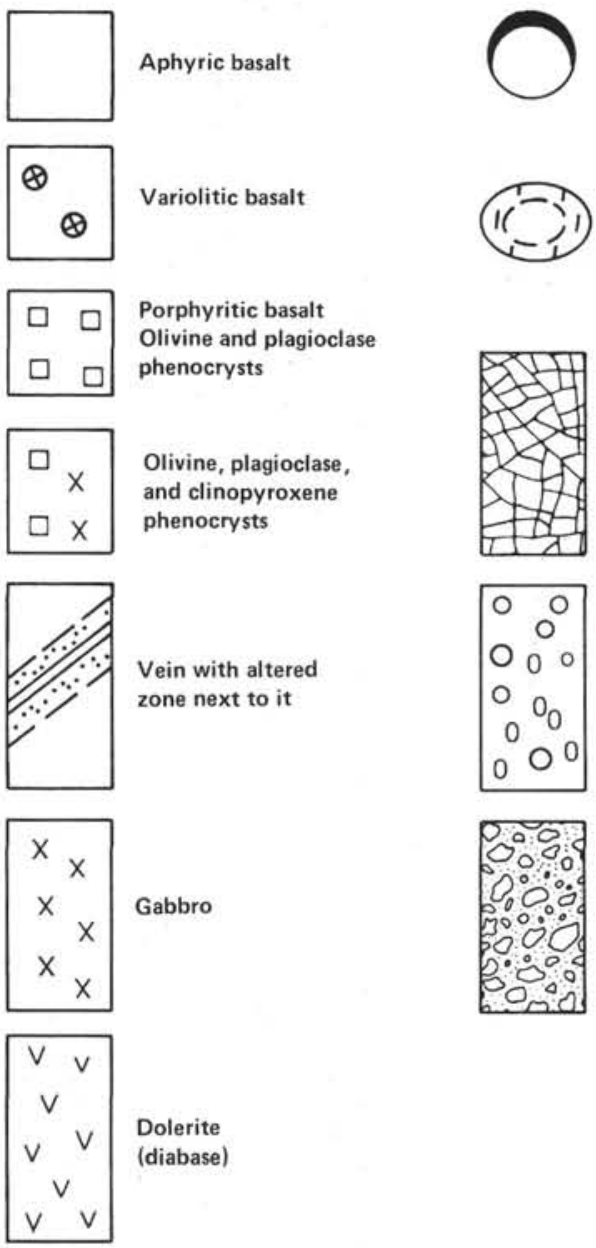

b.
Weathering: Alteration

(used in alteration column)

Glass on edge

(rounded piece)

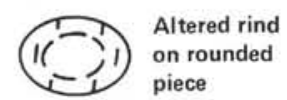

piece

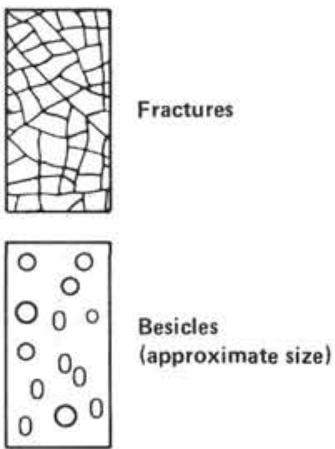

Breccia

(as graphic

as possible)

possible) altered (completely discolored, beginning to disaggregate.

clayey)

Figure 14. List of symbols for igneous rocks. 